Impact of tree planting configuration and grazing restriction on canopy interception and soil hydrological properties: Implications for flood mitigation in silvopastoral systems

Lunka, P.D.; Lunka, P.; Patil, S.D.

\title{
Hydrological Processes
}

DOI:

10.1002/hyp.10630

Published: 15/10/2015

Peer reviewed version

Cyswllt i'r cyhoeddiad / Link to publication

Dyfyniad o'r fersiwn a gyhoeddwyd / Citation for published version (APA):

Lunka, P. D., Lunka, P., \& Patil, S. D. (2015). Impact of tree planting configuration and grazing restriction on canopy interception and soil hydrological properties: Implications for flood mitigation in silvopastoral systems. Hydrological Processes, 30(6), 945-958.

https://doi.org/10.1002/hyp.10630

\section{Hawliau Cyffredinol / General rights}

Copyright and moral rights for the publications made accessible in the public portal are retained by the authors and/or other copyright owners and it is a condition of accessing publications that users recognise and abide by the legal requirements associated with these rights.

- Users may download and print one copy of any publication from the public portal for the purpose of private study or research.

- You may not further distribute the material or use it for any profit-making activity or commercial gain

- You may freely distribute the URL identifying the publication in the public portal ?

Take down policy

If you believe that this document breaches copyright please contact us providing details, and we will remove access to the work immediately and investigate your claim. 


\title{
Impact of tree planting configuration and grazing
}

\section{restriction on canopy interception and soil hydrological}

\section{properties: Implications for flood mitigation in}

\author{
silvopastoral systems
}
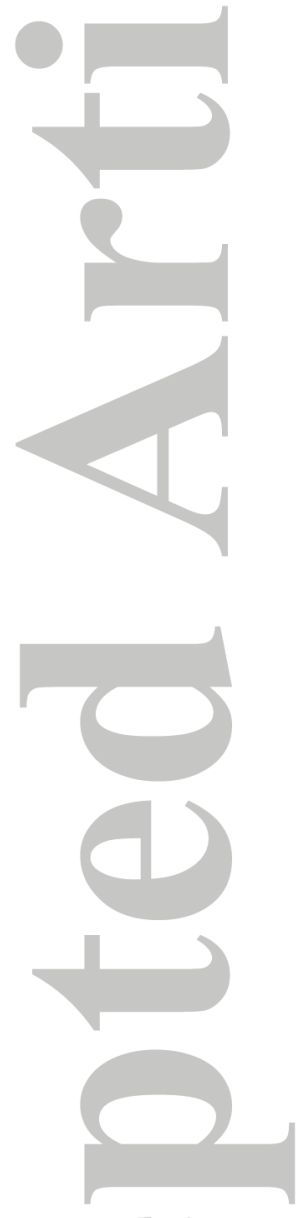

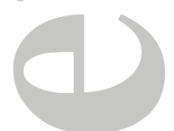

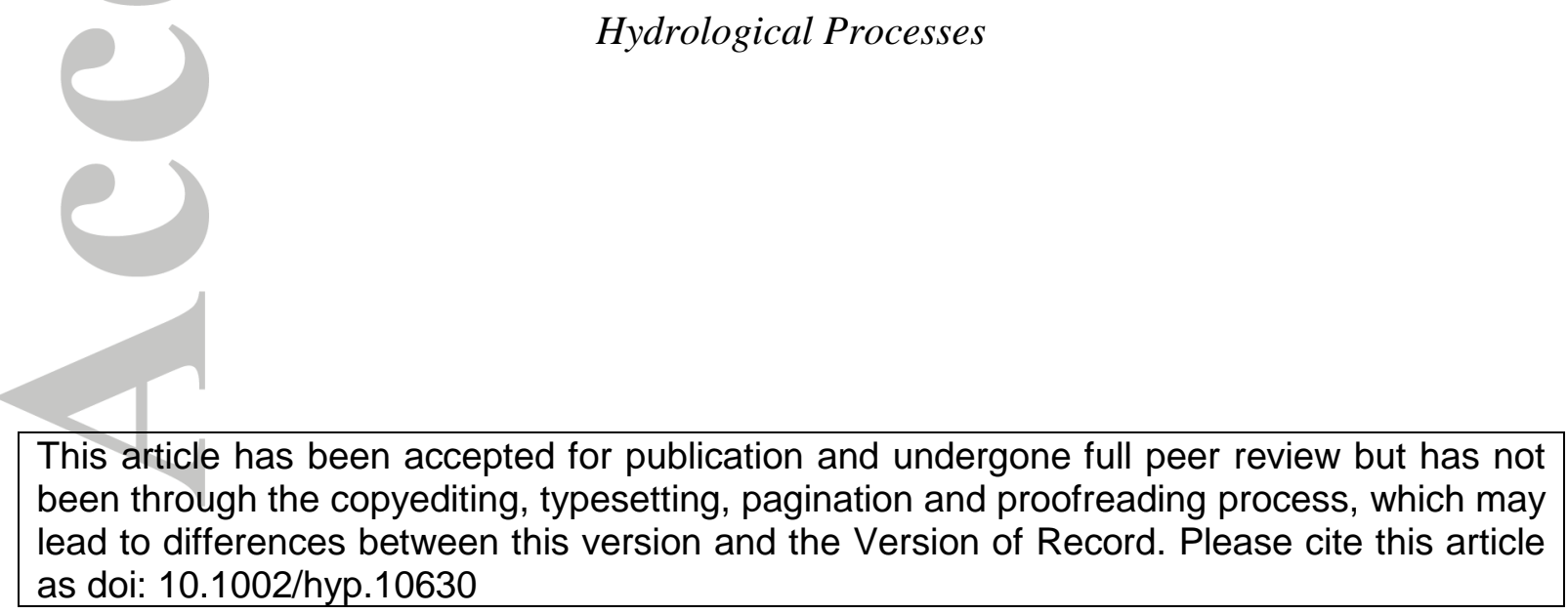

${ }^{1}$ School of Environment, Natural Resources and Geography Bangor University, Bangor LL57 2UW, UK

Corresponding author: lunkap@gmail.com

Submission to:

This article is protected by copyright. All rights reserved. 


\begin{abstract}
Compaction of upper soil layers by intensive sheep grazing has been connected with increased local flood risk in silvopastoral systems. A 12 week field study was conducted at the Henfaes Research Station near Bangor, Wales to compare canopy interception, soil water infiltration, and bulk density between a control pasture and two silvopastoral tree planting configurations: trees clumped in fenced-off ungrazed plots and trees planted evenly and grazed. The study's aim was to characterize the potential of these tree planting configurations to reduce local flood risk. Automated throughfall gauges were installed in each silvopastoral treatment along with a similarly designed control gauge located in the grazed control pasture. Soil water infiltration and bulk density were measured 20 times in a stratified random design for each treatment and control. Results showed that the mean soil infiltration capacity in clumped configuration was $504 \%$ greater than the control pasture and $454 \%$ greater than the even spaced configuration. Average canopy interception was higher in the clumped configuration (34\%) than in the even spaced configuration (28\%). Soil bulk density was lower in the clumped configuration $\left(0.87 \mathrm{Mg} / \mathrm{m}^{3}\right)$ than in the control pasture $\left(0.93 \mathrm{Mg} / \mathrm{m}^{3}\right)$ and even spaced configuration $\left(1 \mathrm{Mg} / \mathrm{m}^{3}\right)$. Results suggest that silvopastoral systems are more likely to benefit from clumped and ungrazed tree configurations than from evenly-spaced and grazed tree configurations due to enhanced infiltration, lower soil compaction, and increased canopy interception. Our findings support the growing evidence base that fenced-off tree areas in silvopastoral settings can increase infiltration and thus reduce local flood risk.
\end{abstract}

Key words: Infiltration, canopy interception, bulk density, silvopasture, flood risk 


\section{Introduction}

Contemporary climate projections for the United Kingdom (UK) stipulate that flood risk will increase due to precipitation events becoming more frequent and severe [Kay and Jones, 2012]. Lenderink and Van Meijgaard, [2008] reported when temperatures are $12^{\circ} \mathrm{C}$ or greater $1 \mathrm{hr}$ rainfall extremes increased at two times the rate of the Clausius - Clapeyron relationship in De Bilt, Neatherlands, and is modeled to increase $25 \%$ per 1 degree of warming in North Wales. The exceptional floods of 2013/2014 resulted in the Department of Environment, Food and Rural Affairs (Defra) to contribute an additional $£ 270$ million for pressing repairs, maintenance and restoration of flood defenses [DEFRA and EA, 2014]. Flood risk is clearly a concern, and protecting and improving the water environment is the principal aim of the European Union (EU) Water Framework Directive and Welsh Assembly Government's (WAG) Woodlands for Wales Strategy [Nisbet et al., 2011]. The ability of woodlands to prevent flooding has been debated in the UK with proponents for flood alleviation arguing that the interception of precipitation by tree canopies and forests enhance infiltration rates and reduce flood risk. The sceptics argue that most large storms occur in the winter and saturate the already wet soils reducing the soil's capacity to store water and canopy interception can decline to zero during infrequent large precipitation events [Forestry Commission, 2014]. Consequently, there has been considerable effort to review relevant literature relating to woodlands and flooding and to determine the optimal methods and locations to mitigate flood risk [Nisbet et al., 2011]. Wales is one of the least forested countries in Europe with forest covering 14\% of the land area; the UK has $13 \%$ forest cover [Forestry Commssion Wales, 2009]. Hence, interest in woodland creation to mitigate flood risk has expanded beyond traditional woodlands to include planting of tree shelter belts on farms and pasture lands as extensive pasture lands in Wales have been seen as a likely cause of flooding [Nisbet et al., 2011]. 
Current research is building strong links between sheep grazing, flooding, and the benefits of tree shelter belts. Several studies have demonstrated that the removal of sheep from pastures reduces run-off volumes [Greenwood et al.,1998; Nguyen et al., 1998; Carroll et al., 2002; Carroll et al., 2004; Marshall et al., 2009; McIntyre and Marshall, 2010; Marshall et al., 2014]. Moreover, the planting of tree shelter belts produces a similar hydrologic response to the removal of sheep from pastures but to greater effect [Carroll et al., 2004; Marshall et al., 2009; Marshall et al., 2014]. However, there has been limited success so far in proving that small scale changes in runoff proliferate downstream at the large catchment scale [O'Connell et al., 2004; Parrott et al., 2009]. Nevertheless, UK government policy recognizes that land management strategies such as tree shelter belts are likely to improve local flood mitigation and water quality to help meet the EU Water Framework Directives (WFD) [Nisbet et al., 2011].

Tree shelter belts can be incorporated as a component of silvopastoral systems that have the potential to provide a variety of ecosystem services. Silvopastoral systems are part of agroforestry systems and are animal production systems that merge fodder plants, such as grasses and leguminous herbs, with shrubs and trees for animal nutrition and complementary uses [Mahecha and Angulo, 2012]. Silvopastoral systems are not commonly used in the UK but provide great opportunities for enhanced environmental, economic, and social benefits. They are rare in part due to no major incentives, like for agriculture or forestry, in the EU Common Agricultural Policy (CAP) [Sibbald, 2006]. This puts silvopastoral systems at an economic disadvantage which has resulted in low uptake by landowners [Sibbald, 2006]. More recently, Nisbet et al. [2011] also cited poor economic incentives for landowners to plant trees on farms and pastures. In Wales, the Glastir land management schemes do not particularly address planting of trees on farms [Wynne-Jones, 2013]. Despite the lack of government incentives, silvopastoral systems have been shown to provide valuable 
ecosystem services and are a viable land management alternative [Teklehaimanot et al., 2002; Sibbald, 2006].

Land management related studies often include soil water infiltration rates and canopy interception as important hydrological processes [Johnson, 1990; Carroll et al., 2004;

Marshall et al., 2014]. Correct determination of infiltration rates is vital for reliable prediction of surface runoff and is necessary for understanding and describing hydrological dynamics at the landscape scale [Lili et al., 2008]. Soil properties such as bulk density are considered to be important parameters in studies investigating flooding on pasture lands and can relate to soil compaction and infiltration rates [Marshall et al., 2014]. Canopy interception is also an important parameter in many hydrological studies [Vegas Galdos et $a l ., 2012$ ] as its accurate quantification is needed to fully understand a watershed's water balance [Savenije, 2004]. Moreover, the impact of soil infiltration and canopy interception processes on flood magnitude and timing is also dependent on the tree planting configurations in agricultural and pasture lands [Carroll et al., 2004]. Therefore, this paper's aim is to compare two different tree planting configurations in a silvopastoral system and characterize their potential to reduce local flood risk. This aim is directly related to an evidence gap stated by Nisbet et al. [2011] on addressing how to best integrate woodland creation within agricultural lands to deliver water resource benefits.

We conducted a 12 week field study at Henfaes Research Station near Bangor, Wales to compare two common silvopastoral configurations, trees planted in un-grazed fenced off clumps and trees planted evenly spaced and grazed, in terms of canopy throughfall, soil water infiltration and soil bulk density. Automated throughfall gauges were installed in each silvopastoral treatment along with a similarly designed control gauge located in the grazed control pasture. We also measured soil water infiltration and bulk density in a stratified random design for each treatment and the control plot. The remainder of the paper is 
organized as follows: Section 2 describes the study site where the field measurements were conducted. Section 3 outlines the methods used for the measurement and analysis of canopy interception, soil infiltration, and bulk density. Section 4 provides a detailed description of the main results of our study, followed by a discussion of the results (Section5) and conclusions (Section 6).

\section{Study Area}

The research site (National Silvopastoral Network Site: Henfaes) is one of the six sites in a national network established across the UK to examine the potential of silvopasture and agroforestry on UK farms [Sibbald et al., 2001]. The Henfaes site was established in 1992 on 14 ha of agricultural land owned by Bangor University at Abergwyngregyn, Gwynedd, $12 \mathrm{~km}$ east from the city of Bangor. The climate at Henfaes is characterized as hyperoceanic, with an annual rainfall of approximately $1000 \mathrm{~mm}$ [Teklehaimanot et al., 2002]. The wettest mean monthly precipitation recorded at Henfaes between 1946-2008 was $324 \mathrm{~mm}$ in November, 2000. Henfaes has an annual rainfall pattern that is similar to the rest of Wales, with the heaviest rainfall occurring in the autumn and winter seasons and with relatively dry spring and summer seasons (Figure 1). Henfaes climate is somewhere between the extremely wet climate characterizing the mountainous areas of North Wales and the relatively drier climate of the western coastal and the eastern parts of Wales.

The soil at Henfaes consists of a fine loamy brown earth overlying gravel (Rheidol series) and is classified in the United Nations Food and Agriculture Organization (FAO) structure as a Dystric Cambisol [Teklehaimanot et al., 2002]. The Rheidol series soil characteristics include good structural stability, moderate water holding capacity and good drainage [Cranfield University, 2014; FAO, 2014]. The soils are suitable for grain crops and permanent pastures, and waterlogging is rare due to good drainage throughout the year 
[Cranfield University, 2014]. The farm site consists of a gently sloping deltaic fan of approximately $1-2^{\circ}$ with a north westerly aspect at $4-14 \mathrm{~m}$ above sea level. The depth of the water table ranges between 1 and $6 \mathrm{~m}$ [Teklehaimanot et al., 2002].

Henfaes has a set of common core tree planting configuration treatments that are described in detail by Teklehaimanot et al. [2002]. The treatments that are relevant to this study include: (1) sycamore (Acer pseudoplatanus L.) planted in even spacing at 400 stems $\mathrm{ha}^{-1}$ on grazed pasture, thinned to $100 \mathrm{stems} \mathrm{ha}^{-1}$ in 2013 , (2) sycamore planted at 400 stems $\mathrm{ha}^{-1}$ but in un-grazed clumps, and (3) a control pasture, which is a grass covered treeless area that is grazed by sheep [Teklehaimanot et al., 2002]. All trees were planted in 1992 and the grazing density is the same for the evenly spaced treatment, the control and the pasture portion of the clumped treatment. Henceforth in this paper, we will refer to the even spaced 100 stem ha $^{-1}$ sycamore configuration as the even spaced treatment and the sycamore 400 stem $\mathrm{ha}^{-1}$ configuration as the clumped treatment.

All field measurements were conducted in Block III of the Henfaes farm, and each treatment has an area of 0.42 ha. Figure 2 shows the layout of Block III with locations of the throughfall gauges, control gauge and the Henfaes weather station. Please note that the satellite image in Figure 2 shows the even spaced treatment plot prior to its thinning in 2013. For the clumped treatment section of the farm, each clump contains thirteen trees with a density of thirty one clumps ha ${ }^{-1}$ with approximately $20 \mathrm{~m}$ distance between the clump centers. The clumped treatment was initiated to examine alternative planting patterns to evenly spaced trees [Teklehaimanot et al., 2002].

\section{Methods}

\subsection{Infiltration measurements}

Soil water infiltration $(I)$ was measured in June, 2014 using a $6.5 \mathrm{~cm}$ diameter single ring infiltrometer by manually maintaining a constant head as per the procedures described in 
McKenzie et al. [2002]. $1000 \mathrm{ml}$ and $50 \mathrm{ml}$ graduated cylinders were used in lieu of Mariotte's bottles. Replicates were randomly stratified by dividing each treatment into rectangular sections. Random numbers were generated to produce $\mathrm{x}$ and $\mathrm{y}$ sampling locations. For the clumped treatment, at least one clump was randomly selected from each of the five rows with 2 replicates per clump. 20 measurements were conducted in the control pasture, 20 in even spaced treatment and 12 within the clumped treatment. The control pasture replicates comprised 12 from the open pasture area and 8 from the pasture located in between the clumped trees; both areas have similar soils, vegetation, topography and sheep stocking densities. Infiltration measurements were conducted until steady state infiltration was observed. Steady state infiltration was determined when identical infiltration rates occur for five successive timed intervals [Mckenzie et al., 2002]. In some instances, as few as three successive intervals were used to determine steady state infiltration rates when differences between intervals were within $+/-2 \mathrm{ml}$. In the clumped treatment, the volume of water added to maintain constant head was recorded at 5 minute intervals or less. In the control pasture and even spaced treatment, intervals ranged from less than 5 to 10 minutes.

Short intervals were generally used at the start of the measurement, to define the initial infiltration curve, and if required at the end of measurement to confirm steady state infiltration. Steady state infiltration $\left(I_{s}\right)$ was then calculated using linear regression, with time (minutes) of the infiltration measurement as the independent variable and infiltration $(I)$ as the dependent variable. Steady state infiltration rate is the slope of the regression line [McKenzie et al., 2002]. Steady state infiltration rate can be approximated as the soil's infiltration capacity $f_{c}[\mathrm{~mm} / \mathrm{h}]$ at field saturation [Bull and Kirkby, 2002]. We further converted this infiltration capacity from depth units $[\mathrm{mm} / \mathrm{h}]$ to a volume per unit area $\left[\mathrm{m}^{3} / \mathrm{h} / \mathrm{ha}\right]$. This was done because the sycamore $400 \mathrm{stems} \mathrm{ha}^{-1}$ clumped treatment had both tree clumps and open pasture patches in the treatment. Therefore, the land area [\%] occupied 
by each part was also considered in the unit conversion. Figure 2 shows the clumped treatment plot containing the clumped trees and the grass pasture separating the clumps. The infiltration capacity for the entire treatment, including the clumps and the pasture part of the treatment, was calculated in the volume per unit area and will be referred to as the aggregated clumped treatment. The clumps occupied $14 \%$ of the treatment and the pasture was the remaining $86 \%$. Therefore, the aggregated clumped infiltration capacity at field saturation $F_{c a}$ $\left[\mathrm{m}^{3} / \mathrm{h} / \mathrm{ha}\right]$ for each treatment was calculated as follows with $I_{s} c$, infiltration from clumps, and $I_{S} O$, infiltration from open fraction:

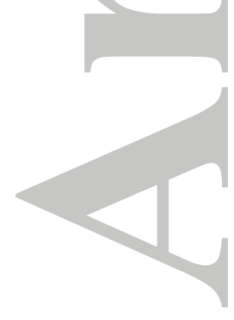

$$
F_{c a}=10 *\left(0.14 * I_{s} c+0.86 * I_{s} o\right)
$$

\subsection{Bulk density measurements and soil analysis}

Bulk density $\left(P_{b}\right)$ measurements were conducted in June, 2014 adjacent to all infiltration measurements at a distance of one to two times the radius of the infiltrometer ring [McKenzie et al., 2002]. A bulk density ring with a volume of $100 \mathrm{ml}$ and $7.5 \mathrm{~cm}$ depth was used to extract the soil core. Surface vegetation was removed with knife and trowel and care was taken to not disturb the soil surface. The soil cores were placed into sealed bags and put into cold storage within 12 hours of sampling. Bulk density $\left[\mathrm{Mg} / \mathrm{m}^{3}\right]$ of the fine particles was calculated by weighing the field soil, drying the known volume of soil at $105^{\circ} \mathrm{C}$ for $48 \mathrm{~h}$ and re-weighing the dried soil [McKenzie et al., 2002]. After the soil was dried and weighed rock particles $>2 \mathrm{~mm}$ were sieved out from each sample and weighed. The stones weight was subtracted from the total sample weight to obtain fine particle soil sample used in the bulk density equation. The following soil parameters were also calculated for each sample: particle density $P_{s}\left[\mathrm{Mg} / \mathrm{m}^{3}\right]$, soil porosity $\phi[\%]$, gravimetric water content $\Theta_{\mathrm{g}}[\%]$, volumetric water content $\Theta_{\mathrm{v}}[\%]$, and air filled porosity $\phi_{\mathrm{a}}[\%]$. The soil particle density was 
assumed to be $2.65 \mathrm{Mg} / \mathrm{m}^{3}$ which is the standard approximation for most mineral soils [McKenzie et al., 2002].

\subsection{Canopy interception measurements}

Canopy interception measurements were based on the experimental setup described by Asadian and Weiler [2009]. The throughfall gauges collected data between 26 May, 2014 and 28 July, 2014. Three throughfall gauges were installed in Block III of the Henfaes site: one in the even spaced treatment, one within the clumped treatment, and one control gauge in the open pasture (Figure 2). One gauge per plot was deemed sufficient to measure throughfall due to the small area of the plots (0.42 ha). Moreover, the age, forest structure and tree species were the same for both treatment plots. While our original intent was to install the gauges in the middle of each treatments plot, this was not possible due to the following reasons. For clumped treatment the middle clump plot's fence was damaged, which permitted sheep access. Therefore, the next nearest clump was used instead. For even spaced treatment, the central tree's canopy was not suitable for logistical reasons. The branches were too high to safely secure the throughfall collectors. Fall protection gear would have been required which was beyond the scope of our health and safety plan. Therefore, the next nearest tree was selected. Similar to Asadian and Weiler (2009), two 3 m long and 76 $\mathrm{mm}$ diameter PVC pipes were positioned underneath the canopy using a rope to ensure that the entire diameter of the tree canopy was covered. Three slits were cut out in each pipe, $0.85 \mathrm{~m}$ length and $0.028 \mathrm{~m}$ wide, for a total area of $0.1428 \mathrm{~m}^{2}$. A $0.034 \mathrm{~m}^{2}$ (RAINEW, RainWise Inc., Bar Harbour, ME) tipping rain gauge was place below the PVC pipes and was connected to a Sky Instruments Limited Helio Mini data logger. Air temperature $\left[{ }^{\circ} \mathrm{C}\right]$, soil temperature measured at $5 \mathrm{~cm}$ depth $\left[{ }^{\circ} \mathrm{C}\right]$, relative humidity [\%] and throughfall/rainfall [mm] were recorded at 15 minute intervals. The tipping rain gauge was leveled and mounted to the 
tree with a plywood roof to ensure that the pipes were the only source of throughfall collection (see Figure 3).

The control gauge was installed in a similar fashion in the open pasture at a distance that was twice the height away from the nearest obstruction, such as trees or buildings [NOAA, 2002]. The data logger was installed perpendicular to the covered rain gauge to ensure that it did not obstruct the collecting pipes. The control gauge was used to compare the effectiveness of the design by comparing gross rainfall values to Henfaes weather station. Canopy interception was calculated as follows:

$$
I_{c}=P_{g}-T_{f}
$$

Where, $I_{c}$ is the canopy interception $[\mathrm{mm}], P_{g}$ is the gross precipitation, measured above canopy or in an open area [mm], and $T_{F}$ is the throughfall, i.e., precipitation that passes through the canopy or as drip from the vegetation [mm]. Several UK studies have found average stemflow values to be $5 \%$, often less, of the total above canopy precipitation [Johnson, 1990; Neal et al., 1993; Herbst et al., 2008]. Therefore, stemflow was neglected in our calculation of canopy interception due to stemflow's small effect on canopy throughfall. The control gauge and the on-site Henfaes weather station were used for $P_{g}$ measurements throughout the study period (Figure 2).

\subsection{Statistical analyses}

Similar statistical methods were implemented for infiltration, bulk density and additional soil parameters. One way Analysis of Variance (ANOVA) test was conducted for soil bulk density and the additional soil parameters (porosity, volumetric water content, volumetric air content) data to determine if the mean values for different treatments were statistically different [Fisher, 1937]. All statistical tests had significance levels set to 0.05, and the corresponding confidence intervals were 95\%. Fisher's least significant difference test (Post-hoc LSD test) was further used if the ANOVA test confirmed that the means were 
not equal. Fisher's post-hoc LSD test identifies which particular treatments means are statistically different and is similar to a series of individual t-tests with the exception of the standard deviation being pooled from all treatment groups increasing the power of the test [Williams and Abdi, 2010]. Soil infiltration data did not meet the homogeneity of variance assumption for the one way ANOVA test. Therefore, Krusal-Wallis test, which is a nonparametric equivalent to one way ANOVA test, was selected [Dytham, 2011]. The KruskalWallis test does not assume normal distribution; therefore, the median of the treatments are compared, using ranks, to determine if they are statistically different [Kruskal and Wallis, 1952]. A non-parametric post-hoc multiple comparisons using rank sums test (DunnBonferroni test) was used to identify which particular treatments medians were different [Dunn, 1964]. This test was selected as it is a non-parametric alternative to Fisher's post-hoc LSD test [Dytham, 2011].

Linear regression relationship was developed between the untransformed rainfall data and throughfall measurements after initial analyses showed their residuals to be normally distributed with no distinguishable curve in the residual plot [Seal, 1967]. An analysis of covariance (ANCOVA) test was used to determine if the coefficients and slope of the regression relationships were significantly different among the two treatments, after accounting for the effect of rainfall on throughfall [Dytham, 2011].

\section{Results}

\subsection{Soil water infiltration}

The mean infiltration capacity was $209 \mathrm{~mm} / \mathrm{h}$ for the clumped treatment, $35 \mathrm{~mm}$ for the even spaced treatment, and $38 \mathrm{~mm}$ for the control pasture plot (Figure 4). When the clumped sycamore treatment was aggregated, including clumps of trees and pasture part of the treatment, the clumps treatment's mean infiltration capacity was $532.3 \mathrm{~m}^{3} / \mathrm{h} /$ ha. This 
was considerably higher than the even spaced treatment $\left(345.3 \mathrm{~m}^{3} / \mathrm{h} / \mathrm{ha}\right)$ and the control pasture $\left(376.6 \mathrm{~m}^{3} / \mathrm{h} / \mathrm{ha}\right.$; also see Figure 4$)$.

The Kruskal-Wallis test on infiltration capacity data showed that significant difference existed between the clumped and even spaced treatments $(\mathrm{P}<0.01)$. The DunnBonferroni multiple pairwise test showed that the clumped treatment had significantly higher infiltration capacities than all other treatments $(\mathrm{P}<0.01)$. No significant difference in infiltration capacity was observed between the control pasture and even spaced treatment. The Kruskal-Wallis test on aggregated infiltration capacity data also showed similar results $(\mathrm{P}=0.02)$. The Dunn-Bonferroni multiple pairwise test showed that the aggregated clumped treatment had significantly higher infiltration capacity $(\mathrm{P}=0.02)$ than the even spaced treatment; however, no significant difference was observed between the aggregated clumped treatment and the control pasture and no significant difference existed between the even spaced and control pasture plots.

Table 1 shows the mean infiltration capacities expressed in depth units $[\mathrm{mm} / \mathrm{h}]$ and also as volume per unit area $\left[\mathrm{m}^{3} / \mathrm{h} / \mathrm{ha}\right]$. The aggregated clumped treatment $\left[\mathrm{m}^{3} / \mathrm{h} / \mathrm{ha}\right]$ had $54 \%$ greater infiltration capacity than even spaced and $41 \%$ greater than control pasture plots. The treed clumps infiltration capacity $[\mathrm{mm} / \mathrm{h}]$ averaged $504 \%$ greater than the even spaced plot and $454 \%$ greater than the control pasture.

\subsection{Bulk density and additional soil parameters}

Mean bulk density was $0.87 \mathrm{Mg} / \mathrm{m}^{3}$ for the clumped treatment, $1.00 \mathrm{Mg} / \mathrm{m}^{3}$ for the even spaced treatment, and $0.93 \mathrm{Mg} / \mathrm{m}^{3}$ for the control plot (Figure 5). One way ANOVA test on the soil bulk density data showed that significant difference existed between the clumped and even spaced treatments $(\mathrm{P}<0.01)$. The post-hoc LSD test showed that the treed clumps had significantly lower mean bulk density than all other treatments $(\mathrm{P}<0.01)$. 
Mean soil porosity was $67 \%$ for clumped treatment, $62 \%$ for even spaced treatment, and $65 \%$ for the control plot (Figure 6). The volumetric water content was similar in the control pasture and even spaced treatment plot (40\% and 38\% respectively) and the clumped treatment plot had considerably lower moisture levels at 28\% (Figure 6). The air porosity was highest in the clumped treatment plot at $39 \%$ and lower in the control pasture, $25 \%$, and even spaced treatment plot, $24 \%$.

Table 2 summarizes the statistical tests conducted on the soil porosity, soil volumetric water and soil volumetric air porosity measurements. All tests showed statistically significant differences $(\mathrm{P}<0.01)$ for soil porosity, volumetric water content and air filled porosity between treatments with the exception of the following results. The post-hoc LSD test found no significant difference for volumetric water content between the pasture and the even spaced treatments. The volumetric air content had no significant difference between the pasture and even spaced treatments.

\subsection{Canopy interception}

A distinct linear relationship was observed between rainfall and canopy throughfall amounts for both silvopastoral treatments (Figure 7). The slope of the linear regression relationship between rainfall and even spaced treatment's throughfall is 0.725 and the intercept is $2.673\left(\mathrm{R}^{2}=0.997\right)$. For clumped treatment, the slope of the linear regression relationship between rainfall and canopy throughfall is 0.659 and the intercept is $1.996\left(\mathrm{R}^{2}=\right.$ 0.996). The ANCOVA test showed that there was a significant difference between the canopy throughfall amounts for the clumped and even spaced treatments, once the effect of rainfall is accounted for $(\mathrm{P}<0.01)$. The slope of the linear regression relationship for the clumped treatment is shallower than that for the even spaced treatment (Figure 7). This suggests that the clumped treatment is a better interceptor of rainfall than the even spaced treatment. 
There was considerable temporal variation in throughfall and interception amounts at the storm scale throughout the experimental period. The even spaced configuration averaged $28 \%$ interception throughout the twelve week experimental period and the clumped tree configuration averaged 34\% interception. The total rainfall for the experimental period was $80 \mathrm{~mm}$ and event based interception rates ranged from $100 \%$ to $2 \%$ (Table 3 ). There were fifteen rainfall events when there was no throughfall (i.e., $100 \%$ interception occurred); all of these rain events had $0.5 \mathrm{~mm}$ of rainfall or less, except for one $2.8 \mathrm{~mm}$ event (see Appendix A). Four larger events (> $6 \mathrm{~mm}$ rainfall) captured by the automated throughfall collectors produced interception rates ranging from $2 \%$ to $30 \%$. The rainfall gauge installed in the control pasture most likely malfunctioned for part of the experimental period. For some rainfall events between July $7^{\text {th }}$ and July $28^{\text {th }}$, the control gauge recorded lower amount of rainfall than the treatment gauges (Appendix A). We suspect that this may have occurred due to mud or pollen clogging the control gauge. Therefore, for this duration, we used the data from Henfaes weather station as control measurements. Generally, small rainfall events $(<$ $6 \mathrm{~mm})$ had $>50 \%$ interception, with the exception of events 5, 9, 10 and 17 . Throughfall delay was typically short for the moderate events, 15 minutes or less (except for event 4) and was similar between the two treatments. Interception rates of individual events were variable between the treatments, but with no obvious temporal pattern.

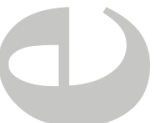

\section{Discussion}

Results show that the soil infiltration capacity is significantly higher in the clumped treatment than in the control pasture as well as the grazed even spaced treatment. These finding are consistent with Marshall et al. [2014], who found significant differences between infiltration rates of protected tree belts and the control pasture; but not between the un-grazed pasture and the control pasture. Carroll et al. [2004] quantified infiltration rates sixty times 
greater within a pasture planted with young trees compared to an adjacent pasture. Marshall et al. [2014] also reported the infiltration rate ratio of 67:1 for treed un-grazed plot to grazed control plot. In comparison, our results showed much smaller ratios, 4.5:1 for the un-grazed clumped treatment versus grazed pasture and 5:1 for the un-grazed clumped treatment to the grazed even spaced treatment (Table 1). While our numbers are much lower than Marshall et al. [2014] and Carroll et al. [2004], this discrepancy could be attributed to the seasonal and inter-annual variability of soil structure and the accompanying hydrological response [Leitinger et al., 2010]. The area averaged infiltration capacity for the aggregated clumped treatment, as expressed in volume per area, was also found to be greater in the clumped treatment, including clumps and pasture section of the treatment, than in the even spaced treatment. As the tree clumps were fenced off, compaction of the top layers of soil from livestock was limited, which likely resulted in the increased infiltration rates [Greenwood et al., 1998; Nguyen et al., 1998; Carroll et al., 2002; Carroll et al., 2004]. It is likely that the combination of livestock exclusion, tree root development, denser litter fall and associated micro faunal activity resulted in much higher infiltration capacities within the clumped tree treatment plot. Marshall et al. [2014] showed that although removal of livestock increases infiltration and reduces run-off, the addition of trees to an un-grazed area produces even greater benefits.

As trees increase soil water infiltration through tree root development [Bharati et al., 2002], we had an a priori expectation that the even spaced treatment would have higher infiltration capacities than the control pasture despite the presence of grazing sheep. However, no significant difference was observed between them. One likely cause for this is that the soil compaction by sheep near the tree bases in the even spaced treatment plot reduced infiltration rates by restricting root development and the creation of macropores through micro faunal activity [Sibbald et al., 2001; Bharati et al., 2002]. Figure 4 shows that 
the confidence interval for infiltration capacity is substantially wider for the even spaced treatment than for the control pasture, which may be due to greater heterogeneity in compaction in the even spaced plot from sheep using trees for shelter. Consistent with Marshall et al. [2014], we found significantly lower bulk densities within the treed clumps than in the control pasture. These results support the evidence for the relationship between increased tree stocking densities, compaction and decreased infiltration argued by $O^{\prime}$ Connell et al., [2007]. Surprisingly, the even spaced treatment had the highest bulk density values. This may be due to soil compaction from sheep that use trees for shelter in the even spaced plot [Sibbald et al., 2001].

We observed greater canopy interception in the clumped treatment than in the even spaced treatment. This is consistent with the studies by Teklehaimanot and Jarvis [1991] and Teklehaimanot et al. [1991] at a silvopastoral system in Glentress Forest, Scotland, where they found that wider spaced tree configurations had lower canopy interception rates. Most likely reason for such variation is that different canopy structures develop from different tree densities [Asadian and Weiler, 2009; Nisbet, 2005]. The average canopy interception rates measured in our study, $28 \%$ for the even spaced treatment and $34 \%$ for the clumped treatment, are on the higher side among various UK interception studies which have found that broadleaved trees intercept $10 \%-25 \%$ of gross precipitation [Calder et al., 2003]. Studies outside the UK have reported interception losses ranging from 10 to $20 \%$ for broadleaved trees [Link et al., 2004, Llorens and Domingo, 2007]. However, our measurements were made during the growing season, which might have contributed to the overall higher interception values.

Despite the relatively high average interception rates, both treatments had large temporal variation in interception rates at the storm scale. The four larger rain events $(>6$ $\mathrm{mm}$ ) had low interception values, all below $26 \%$ with the exception of the clumped trees 
intercepting $31 \%$ and $39 \%$ during two of the events (Table 3). The lower interception rates can partly be explained by intense rain events causing shoots to reach their maximum interception capacity. The absolute daily maximum interception loss can be $6-7 \mathrm{~mm} \mathrm{~d}^{-1}$, depending on LAI and the type of leaf [Calder et al., 2002]. The higher interception rates for the clumped treatment were possibly due to greater LAI from a denser canopy structure. Storms with $<6 \mathrm{~mm}$ of rain typically had interception rates $>50 \%$ (Table 3 ) and in many instances $100 \%$ during small rain events (Appendix A). These results are consistent with Calder et al. [2002] who found that the variation in interception rates depended on storm intensity, and are reasonable given that storms with high rainfall intensity are more likely to surpass daily maximum interception loss capacities than the low intensity storms.

This experiment has shown infiltration, bulk density and sheep grazing can be closely related. Many studies have found sheep grazing and/or mechanical machinery associated with agriculture has a greater effect on infiltration rates and bulk densities than tree root development, litter fall, macro faunal activity and forest canopy interception. Significantly higher infiltration rates and lower bulk densities have been measured in forests compared to pastures in locations outside of the UK ([Bormann and Klaassen, 2008; Price et al., 2010]). Price et.al, [2010] measured saturated hydraulic conductivity and bulk density on two soil types and found significantly lower bulk densities and higher saturated hydraulic conductivities in forest soils than pastures. Price et.al, [2010] and Bormann and Klaassen [2008] contributed the differences to compaction of the pastures due to land management practices. Our results reflect the published literature in the UK and elsewhere with significantly lower bulk densities and higher infiltration capacities within the treed clumps than the pasture and even spaced treatment. As the evenly spaced trees preformed similarly to the pasture control it is likely that the fencing around the clumps restricting sheep grazing and associated compaction was a far greater factor than tree root/micro faunal development 
and litter fall. Clearly, compaction degrades the soil structure and decreases infiltration rates. Conversely, our study has shown infiltration rates and likely soil structure can dramatically recover by restricting grazing and introducing trees.

Forests hydrologic recovery after disturbance is an important and conflicting area of study. The soils in the treed clumps at the Henfaes experiment appear to have related hydrologic functions of a natural forest. Greenwood and Buttle, [2014] reported increases in a secondary forest's near surface saturated hydraulic conductivity were correlated to forest management practices such as pruning and thinning likely increasing understory growth leading to more root and macropore development. The treed clumps in Henfaes had extensive understory growth of various herbaceous plants likely due restriction on grazing and herbicide application. The understory growth may have contributed to greater root and macropore development likely enhancing infiltration rates. Bruijnzeel, [2004] completed a survey of literature related to differences in hydrologic processes of natural forests, secondary forests and conversions of forests to different land uses. Bruijnzeel [2004] concluded that secondary forests can reduce peak flows; however, no evidence exists for secondary forests increasing low flows. Krishnaswamy et al., [2013] supports this conclusion by finding natural forests have higher infiltration rates and ground water recharge than degraded forests; this argument supports the infiltration-evaporation trade off hypothesis in which infiltration differences between land covers rather than evapotranspiration is the primary process regulating low flows. Clearly, the treed clumps provide greatly enhanced infiltration rates with the likely ability to reduce peak flows and possibly the ability to sustain low flows mimicking a natural forest.

The soil infiltration rates measured in the clumps provide the best opportunity of reducing peak flows. The infiltration measurements for this study were conducted in the late spring and the infiltration capacities are generally above all but the most extreme UK hourly 
precipitation events [Met Office, 2015]. However, Hu et al., [2009] found seasonal differences in unsaturated hydraulic conductivities. A pilot study for this experiment was conducted in early March 2014. Infiltration capacities for the pasture control were $6 \mathrm{~mm} / \mathrm{hr}$, $10 \mathrm{~mm} / \mathrm{hr}$ for the even spaced treatment and $334 \mathrm{~mm} / \mathrm{hr}$ for the clumped trees [Lunka, 2014]. During extreme winter rainfall in January and February of 2004 Capel Curig, 17 km from Henfaes, received $13 \mathrm{~mm}$ of rainfall in 1 hour, $34.2 \mathrm{~mm}$ in 3 hours and $169.2 \mathrm{~mm}$ in a 24 hour period [Sibley, 2005]. This caused wide spread flooding throughout Wales [Sibley, 2005]. The 2004 extreme rainfall would cause overland flow in the pasture and even spaced treatments, The clump treatment could infiltrate all the rainfall entering the clump potentially reducing field scale flooding. Unfortunately, canopy interception will not have the same effect as increased infiltration rates on mitigating peak flows as the interception threshold of 6-7 $\mathrm{mm} \mathrm{d}^{-1}$ observed by Calder et al., [2002] is not near the hourly infiltration rates measured in the even spaced and pasture control, refer to Figure 4. Moreover, canopy interception rates for storms $>6 \mathrm{~mm}$ were all below $26 \%$, refer to Table 3 .

Several assumptions and simplifications were made in the design and conduct of our field study, which could potentially influence our findings. One methodological simplification during the design of our experimental work was the use of a single ringed infiltrometer for measuring soil water infiltration. A single ringed infiltrometer was primarily selected to facilitate the measurement of more replicates, to allow for statistically relevant comparisons between treatments, by minimizing the time required for installation and water transport. Single ringed infiltrometers have been associated with over estimations of vertical infiltration rates and consequently overestimations of saturated hydraulic conductivity due to water below the cylinder moving laterally as well as vertically [Hossain, 2010]. We used the throughfall collector design based on Asadian and Weiler [2009], as the authors argued that their design had a number of advantages. The collectors were easy to 
build and install, minimized splashing and evaporation and collected spatially variable throughfall. However, this exact type of design appears to have only been conducted once prior to our study, by Asadian \& Weiler [2009], and thus lacks the substantial field trials to completely assess the method's effectiveness. Ziegler et al., [2009] used a similar method employing trough throughfall collectors and reported that correcting for splashing error and conducting dynamic calibrations to adjust for differences in tip volume over the range of observed tipping rates reduced measurement error. The slits at the top of the throughfall troughs used in this study likely mitigated splashing error but dynamic calibrations were not completed, Ziegler et al., [2009] installed four throughfall collectors covering $3.1 \mathrm{~m}^{2}$ in an evergreen forest in Thailand of 0.5 ha, opposed to our 0.42 ha. Selecting one location to measure with $0.142 \mathrm{~m}^{2}$ throughfall collection location may not have accounted for natural variability. However, given that the trees in each treatment were the same age, species and forest structure, throughfall was assumed to have relatively low variability within each treatment.

\section{Conclusions}

This paper presented the results of a 12 week field study that was conducted at Henfaes Research Station near Bangor, Wales to compare two common silvopastoral configurations, trees planted in fenced off clumps and trees planted evenly spaced, in terms of canopy throughfall, soil water infiltration and soil bulk density. Our goal was to characterize the potential of these tree planting configurations in reducing local flood risk. Results showed that the soil infiltration capacity was significantly higher in the clumped configuration than in the even spaced configuration and control pasture; canopy interception was higher in the clumped configuration than in the even spaced configuration; and soil bulk density was lower in the clumped configuration than in the control pasture and evenly spaced 
configuration. These results suggest that silvopastoral systems are more likely to benefit from a clumped tree configuration than the even spaced tree configuration for reducing local flood risk. Our findings support the growing evidence base regarding the creation of fenced off treed areas in silvopastoral and agroforestry setting to reduce local flood risk [Marshall et al., 2009; Marshall et al., 2014]. These results are policy relevant considering that the 'Woodland for Water: Woodland measures for meeting Water Framework Directive objectives' document [Nisbet et al., 2011] recognizes that land management strategies such as tree shelter belts are likely to help meet the EU Water Framework Directive requirements. Planting clumped trees in areas below or at mid-slope will likely provide the optimal effect of reducing local flood flows, as seen at agroforestry systems in other parts of North Wales such as Pontbren [Marshall et al., 2014].

Although Henfaes was chosen as the experimental location due to the previous establishment of silvopastoral treatments, it is located on a flat land, has well drained soils, and is not located directly below steep slopes. Therefore, the effects of tree planting configurations in steeper high run-off areas near the headwaters of catchments and/or on intermittent runoff pathways are still not entirely clear. Additionally, similar experiments conducted year round and for longer duration (> 3 years) can be highly beneficial to understand the effects of seasonality and to minimize any interpretation errors caused by year to year climatic variability. Further research is also needed to compare the different hydrological benefits provided by coniferous or broadleaved tree types planted in tree shelter belts. Despite the developing evidence base regarding the benefits of clumped tree shelter belts, Nisbet et al. [2011] cite poor economic incentives for landowners to plant trees on farms and pastures. In Wales, the Glastir land management schemes do not particularly address the issue of planting of trees on farms [Wynne-Jones, 2013]. Therefore, additional 
research is needed to determine the optimal approaches for creating new financial incentives and/or complimenting existing incentives for agroforestry and silvopastoral systems.

\section{Acknowledgments}

The first author was partially supported by a scholarship from the Scottish Forestry Trust during this project. We thank Megan Lievesley and Andy Smith for assistance with the field supplies and instrumental setup; Mark Hughes for providing data from the Henfaes weather station; Helen Simpson for support during the lab work; and Mark Rayment for his valuable guidance during the early stages of the project.
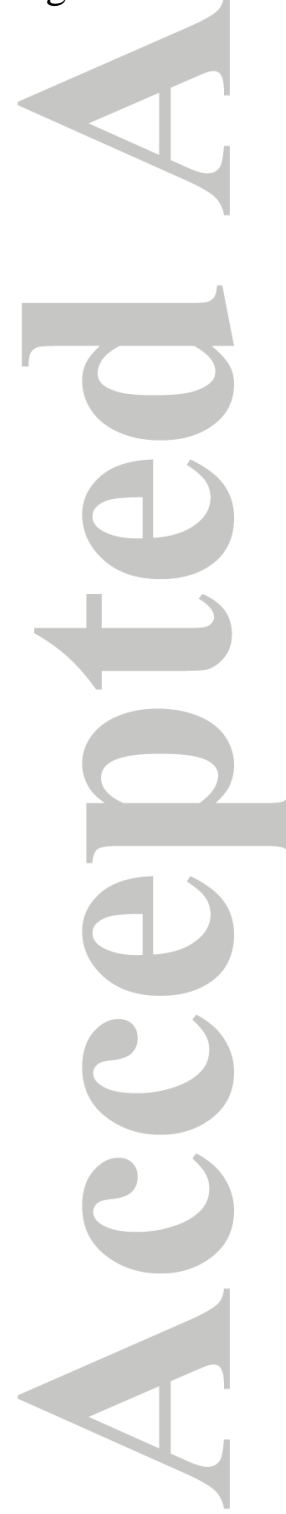


\section{References}

Asadian, Y., and M. Weiler (2009), A new approach in measuring rainfall interception by urban trees in coastal british columbia, Water Qual. Res. J. Can., 44(1), 16-25.

Bharati, L., K. Lee, T. M. Isenhart, and R. C. Schultz (2002), Soil-water infiltration under crops , pasture, and established riparian buffer in Midwestern USA, Agrofor. Syst., 56, 249-257.

Bormann, H., and K. Klaassen (2008), Seasonal and land use dependent variability of soil hydraulic and soil hydrological properties of two Northern German soils, Geoderma, 145(3-4), 295-302, doi:10.1016/j.geoderma.2008.03.017.

Bruijnzeel, L. A. (2004), Hydrological functions of tropical forests: Not seeing the soil for the trees?, in Agriculture, Ecosystems and Environment, vol. 104, pp. 185-228.

Burgy, R. H., and J. N. Luthin (1956), A test of the single-and double-ring types of infiltrometers, Trans. Am. Geophys. Union, 37, 189-192.

Calder, I. R., I. Reid, T. Nisbet, A. Armstrong, J. C. Green, and G. Parkin (2002), Study of the potential impacts on water resources of proposed afforestation, Loughborough.

Carroll ZL, Bird SB, Emmett BA, Reynolds B, S. F. (2004), Can tree shelter belts on agricultural land reduce flood risk?, Soil Use Manag., 20, 357-359.

Carroll ZL, Reynolds B, Emmett B, Sinclair FL, Ruiz De Ona C, W., and P. (2002), The effect of stocking density on soil in upland Wales Report to Country Council for Wales Report FC 73-02-280. No. 630.

Carter, M. R., and E. G. Gregorich (Eds.) (2008), Soil Sampling and Methods of Analysis, Second., CRC Press Taylor and Francis Group, Boca Raton.

Cranfield University (2014), The Soil Guide, Available from: www.landis.org.uk (Accessed 26 August 2014)

DEFRA, and EA (2014), Policy:Reducing the threats of flooding and coastal change, Available from: https://www.gov.uk/government/policies/reducing-the-threats-of-flooding-and-coastalchange (Accessed 8 July 2014)

This article is protected by copyright. All rights reserved. 
Dunn, O. (1964), Multiple comparisons using rank sums, Technometrics, 6, 241-252, doi:10.1080/00401706.1964.10490181.

Dytham, C. (2011), Choosing and Using Statistics: A Biologist's Guide, Third., Wiley-Blackwell.

FAO: Natural Resource and Environmental (2014), Lecture Notes on the Major Soils of the World: Cambisols (CM), FAO Corp. Doc. Repos. Available from:

http://www.fao.org/docrep/003/y1899e/y1899e08.htm (Accessed 20 August 2014)

Fisher, R. A. (1937), The Design of Experiments, Second., Oliver and Boyd, Edinburgh.

Forestry Commission (2014), Forest Research: Cases for and against forestry reducing flooding, Available from: http://www.forestry.gov.uk/fr/INFD-7T9JF8 (Accessed 5 July 2014)

Forestry Commssion Wales (2009), Woodlands for Wales: The Welsh Assembly Government's Strategy for Woodlands and Trees, Welsh Assembly.

Greenwood KL, MacLeod DA, Scott JM, H. K. (1998), Changes to soil physical properties after grazing exclusion, Soil Use Manag., 14, 19-24.

Greenwood, W. J., and J. M. Buttle (2014), Effects of reforestation on near-surface saturated hydraulic conductivity in a managed forest landscape, southern Ontario, Canada, Ecohydrology, 7, 45-55, doi:10.1002/eco.1320.

Herbst, M., P. T. W. Rosier, D. D. McNeil, R. J. Harding, and D. J. Gowing (2008), Seasonal variability of interception evaporation from the canopy of a mixed deciduous forest, Agric. For. Meteorol., 148(11), 1655-1667, doi:10.1016/j.agrformet.2008.05.011.

Hossain, A. (2010), Fundamentals of Irrigation and On-farm Water Management: Volume 1, First., Springer, New York.

Hu, W., M. Shao, Q. Wang, J. Fan, and R. Horton (2009), Temporal changes of soil hydraulic properties under different land uses, Geoderma, 149(3-4), 355-366, doi:10.1016/j.geoderma.2008.12.016.

Johnson, R. C. (1990), The interception, throughfall and stemflow in a forest in highland Scotland and the comparison with other upland forests in the U.K., J. Hydrol., 118, 281-287.

This article is protected by copyright. All rights reserved. 
Kay, A. L., and D. A. Jones (2012), Transient changes in flood frequency and timing in Britain under potential projections of climate change, Int. J. Climatol., 32, 489-502, doi:10.1002/joc.2288.

Krishnaswamy, J., M. Bonell, B. Venkatesh, B. K. Purandara, K. N. Rakesh, S. Lele, M. C. Kiran, V. Reddy, and S. Badiger (2013), The groundwater recharge response and hydrologic services of tropical humid forest ecosystems to use and reforestation: Support for the "infiltrationevapotranspiration trade-off hypothesis," J. Hydrol., 498, 191-209, doi:10.1016/j.jhydrol.2013.06.034.

Kruskal, W. H., and W. A. Wallis (1952), Use of Ranks in One-Criterion Variance Analysis, J. Am. Stat. Assoc., 47, 583-621, doi:10.1080/01621459.1952.10483441.

Leitinger, G., E. Tasser, C. Newesely, N. Obojes, and U. Tappeiner (2010), Seasonal dynamics of surface runoff in mountain grassland ecosystems differing in land use, J. Hydrol., 385, 95-104, doi:10.1016/j.jhydrol.2010.02.006.

Lenderink, G., and E. Van Meijgaard (2008), Increase in hourly precipitation extremes beyond expectations from temperature changes, Nat. Geosci., 1, 511-514, doi:10.1038/ngeo262.

Lili, M., V. F. Bralts, P. Yinghua, L. Han, and L. Tingwu (2008), Methods for measuring soil infiltration: State of the art, Int. J. Agric. Biol. Eng., 1, 22-30, doi:10.3965/ijabe.v1i1.10.

Link, T. E., M. Unsworth, and D. Marks (2004), The dynamics of rainfall interception by a seasonal temperate rainforest, Agric. For. Meteorol., 124, 171-191, doi:10.1016/j.agrformet.2004.01.010.

Llorens, P., and F. Domingo (2007), Rainfall partitioning by vegetation under Mediterranean conditions. A review of studies in Europe, J. Hydrol., 335, 37-54, doi:10.1016/j.jhydrol.2006.10.032.

Marshall, M. R., O. J. Francis, Z. L. Frogbrook, B. M. Jackson, N. Mcintyre, B. Reynolds, I. Solloway, H. S. Wheater, and J. Chell (2009), The impact of upland land management on flooding : results from an improved pasture hillslope, Hydrol. Process., 475(November 2008), 464-475, doi:10.1002/hyp.

Marshall, M. R., C. E. Ballard, Z. L. Frogbrook, I. Solloway, N. Mclntyre, B. Reynolds, and H. S. Wheater (2014), The impact of rural land management changes on soil hydraulic properties 
and runoff processes: results from experimental plots in upland UK, Hydrol. Process., 28(4), 2617-2629, doi:10.1002/hyp.9826.

McIntyre, N., and M. Marshall (2010), Identification of rural land management signals in runoff response, Hydrol. Process., 24(24), 3521-3534, doi:10.1002/hyp.7774.

Mckenzie, N., K. Coughlan, and H. Cresswell (2002), Soil Physical Measurement and Interpretation for Land Evaluation.

Met Office (2015), UK climate - Extremes, Available from:

http://www.metoffice.gov.uk/public/weather/climate-extremes/\#?tab=climateExtremes (Accessed 1 March 2015)

Neal, C., Robson, A. J., Bhardwaj, C. L., Conway, T., Jeffery, H. A., Neal, M., ... \& Walls, J. (1993), Relationships between precipitation, stemflow and throughfall for a lowland beech plantation, Black Wood, Hampshire, southern England: findings on interception at a forest edge and the effects of storm damage, J. Hydrol., 146, 221-233, doi:10.1016/0022-1694(93)90277-G.

Nguyen, M. L., G. W. Sheath, C. M. Smith, and A. B. Cooper (1998), Impact of cattle treading on hill land: 2. Soil physical properties and contaminant runoff, New Zeal. J. Agric. Res., 41, 279-290, doi:10.1080/00288233.1998.9513312.

Nisbet, T., M. Silgram, N. Shah, K. Morrow, and S. Broadmeadow (2011), Woodland for Water: Woodland measures for meeting Water Framework Directive objectives, Forest Res., Forest Research, Surrey.

NOAA (2002), 8" Standard Rain Gauge, , 1-43. Available from: http://www.srh.noaa.gov/srh/dad/coop/EQUIPMENT.pdf

O'Connell, P. E., J. Ewen, G. O'Donnell, and P. Quinn (2007), Is there a link between agricultural landuse management and flooding?, Hydrol. Earth Syst. Sci., 11(1), 96-107, doi:10.5194/hess-1196-2007.

O'Connell PEO, Beven K, Carney JN, Clements RO, Ewen J, F. H., P. A. Harris G, Hollis J, Morris J, O'Donnell GMO, Packman JC, and T. S. Quinn PF, Rose SC, Shepher M (2004), Review of Impacts of Rural Land Use and Management on Flood Generation. Report A: Impact Study Report. R\&D Technical Report FD2114/TR, London, UK.

This article is protected by copyright. All rights reserved. 
Parrott, A., W. Brooks, O. Harmar, and K. Pygott (2009), Role of rural land use management in flood and coastal risk management, J. Flood Risk Manag., 2, 272-284, doi:10.1111/j.1753-

318X.2009.01044.x.

Price, K., C. R. Jackson, and A. J. Parker (2010), Variation of surficial soil hydraulic properties across land uses in the southern Blue Ridge Mountains, North Carolina, USA, J. Hydrol., 383(3-4), 256268, doi:10.1016/j.jhydrol.2009.12.041.

Savenije, H. H. (2004), The importance of interception and why we should delete the term evapotranspiration from our vocabulary, Hydrol. Process., 18(8), 1507-1511.

Seal, H. L. (1967), Studies in the History of Probability and Statistics. XV The historical development of the Gauss linear model, Biometrika, 54, 1-24, doi:10.1093/biomet/54.1-2.1.

Sibbald, A. R. (2006), Silvopastural Agroforestry: a Land Use for the Future, Scottish For., 60(1), 4-7.

Sibbald, A. R., W. R. Eason, J. H. McAdam, and A. M. Hislop (2001), The establishment phase of a silvopastoral national network experiment in the UK, Agrofor. Syst., 53, 39-53, doi:10.1023/A:1012289504098.

Sibley, A. (2005), Analysis of the heavy orographic rainfall over North Wales, 3 and 4 February 2004, Weather, 60(2), 31-36.

Smith, R. E., K. R. J. Smettem, P. Broadbridge, and D. A. Woolhiser (2002), Infiltration theory for hydrologic applications.

Teklehaimanot, A. Z., and P. G. Jarvis (1991), Direct measurement of evaporation of intercepted water from forest canopies, J. Appl. Ecol., 28, 603-618, doi:10.2307/2404571.

Teklehaimanot, Z., P. G. Jarvis, and D. C. Ledger (1991), Rainfall interception and boundary layer conductance in relation to tree spacing, J. Hydrol., 123, 261-278, doi:10.1016/00221694(91)90094-X.

Teklehaimanot, Z., Jones, M., and Sinclair, F. L. (2002), Tree and livestock productivity in relation to tree planting configuration in a silvopastoral system in North Wales, UK, Agroforest. Syst, 56, 47-55. 
Vegas Galdos, F., C. Álvarez, A. García, and J. a. Revilla (2012), Estimated distributed rainfall interception using a simple conceptual model and Moderate Resolution Imaging Spectroradiometer (MODIS), J. Hydrol., 468-469, 213-228, doi:10.1016/j.jhydrol.2012.08.043.

Williams, L. J., and H. Abdi (2010), Fisher's Least Significant Difference (LSD) Test, Encycl. Res. Des., $1-6$.

Wynne-Jones, S. (2013), Connecting payments for ecosystem services and agri-environment regulation: An analysis of the Welsh Glastir Scheme, J. Rural Stud., 31, 77-86, doi:10.1016/j.jrurstud.2013.01.004.

Ziegler, A. D., T. W. Giambelluca, M. A. Nullet, R. A. Sutherland, C. Tantasarin, J. B. Vogler, and J. N. Negishi (2009), Throughfall in an evergreen-dominated forest stand in northern Thailand: Comparison of mobile and stationary methods, Agric. For. Meteorol., 149(2), 373-384, doi:10.1016/j.agrformet.2008.09.002.

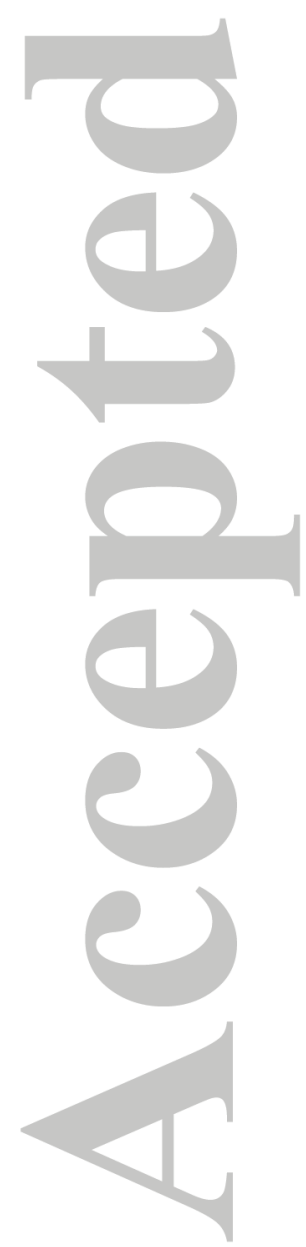

This article is protected by copyright. All rights reserved. 


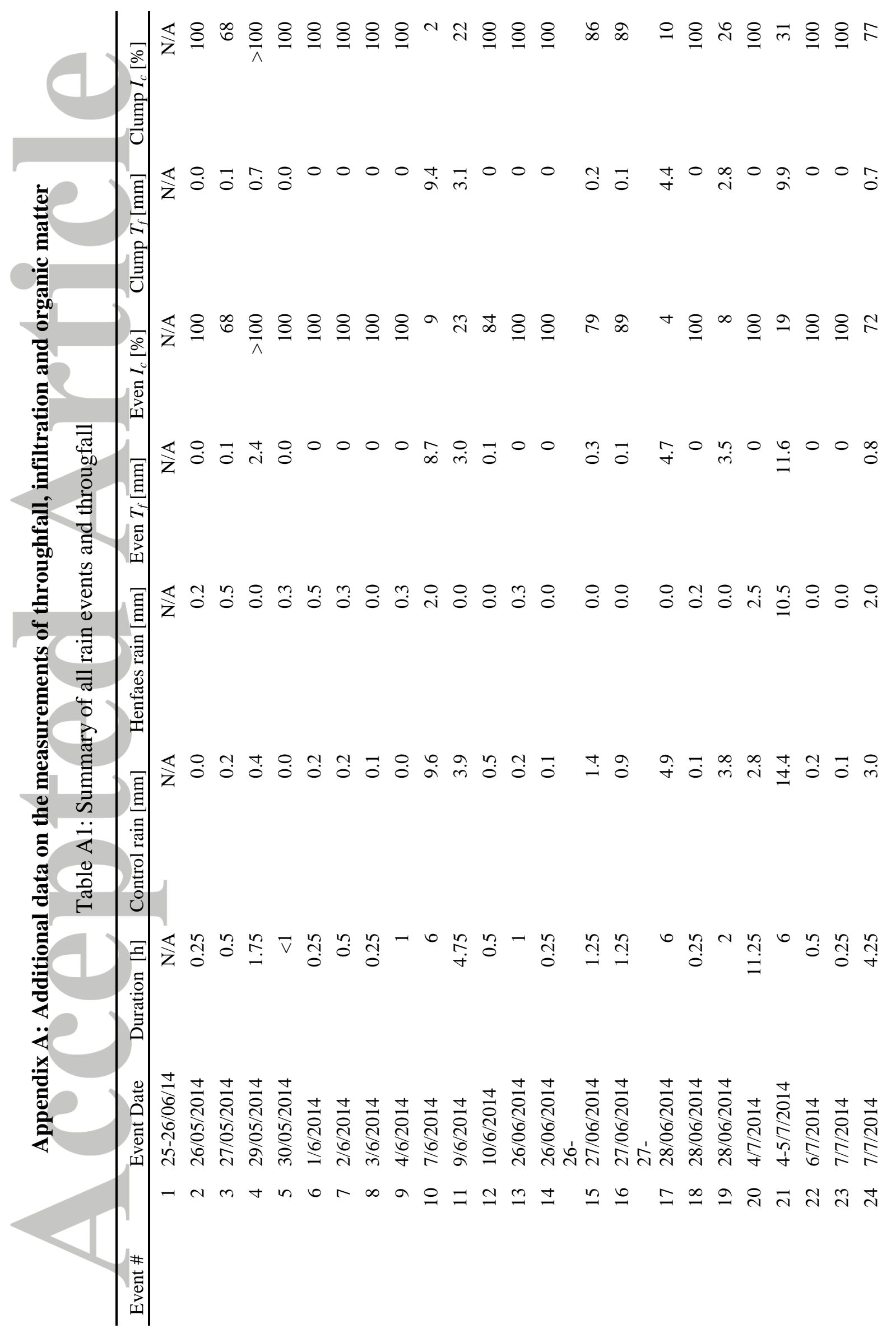

This article is protected by copyright. All rights reserved. 


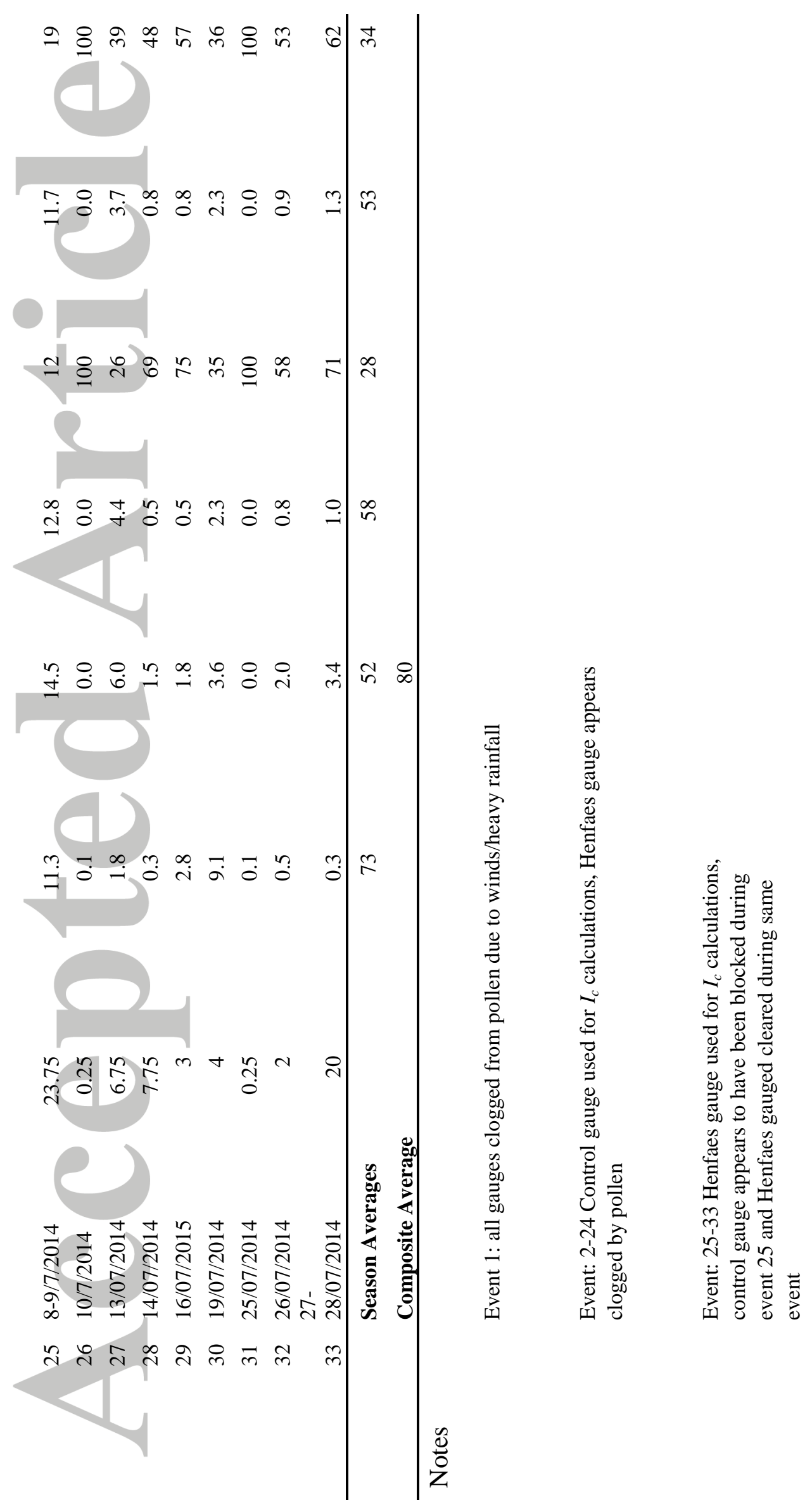

This article is protected by copyright. All rights reserved. 
Table A2: Descriptive statistics of infiltration capacity $[\mathrm{mm} / \mathrm{h}]$

\begin{tabular}{ccccccc}
\hline $\begin{array}{c}\text { Tree } \\
\text { Configuration }\end{array}$ & $\mathrm{N}$ & $\begin{array}{c}\text { Mean } \\
{[\mathrm{mm} / \mathrm{hr}]}\end{array}$ & $\begin{array}{c}\text { Std. } \\
\text { Deviation }\end{array}$ & $\begin{array}{c}\text { Std. } \\
\text { Error }\end{array}$ & Minimum & Maximum \\
\hline Control Pasture & 19 & 37.7 & 24.4 & 5.6 & 4.0 & 92.0 \\
Even Spaced & 20 & 34.6 & 42.5 & 9.5 & 2.0 & 160.0 \\
Clumped & 12 & 209.0 & 103.7 & 29.9 & 77.0 & 398.0 \\
Total & 51 & 76.8 & 93.6 & 13.1 & 2.0 & 398.0 \\
\hline
\end{tabular}

Table A3: Descriptive statistics of aggregated infiltration capacity $\left[\mathrm{m}^{3} / \mathrm{h} / \mathrm{ha}\right]$

\begin{tabular}{|c|c|c|c|c|c|c|}
\hline $\begin{array}{c}\text { Tree } \\
\text { Configuration } \\
\end{array}$ & $\mathrm{N}$ & $\begin{array}{c}\text { Mean } \\
{[\mathrm{m} 3 / \mathrm{hr} / \mathrm{ha}]}\end{array}$ & $\begin{array}{c}\text { Std. } \\
\text { Deviation } \\
\end{array}$ & $\begin{array}{l}\text { Std. } \\
\text { Error }\end{array}$ & Minimum & Maximum \\
\hline Pasture Control & 19 & 376.6 & 244.4 & 56.1 & 36.0 & 922.2 \\
\hline Even Spaced & 20 & 345.3 & 425.4 & 95.1 & 18.0 & 1599.0 \\
\hline Clumps & 12 & 532.3 & 146.9 & 42.4 & 320.7 & 796.9 \\
\hline Total & 51 & 401.0 & 317.2 & 44.4 & 18.0 & 1599.0 \\
\hline
\end{tabular}

Table A3: Descriptive statistics of loss on ignition [\%]

\begin{tabular}{ccccccc}
\hline $\begin{array}{c}\text { Tree } \\
\text { Configuration }\end{array}$ & $\mathrm{N}$ & Mean & $\begin{array}{c}\text { Std. } \\
\text { Deviation }\end{array}$ & Std. Error & Minimum & Maximum \\
\hline Pasture Control & 20 & 9.2 & 0.6 & 0.1 & 7.7 & 10.2 \\
Even Spaced & 20 & 8.0 & 0.8 & 0.2 & 6.5 & 9.3 \\
Clumps & 12 & 8.4 & 0.7 & 0.2 & 7.7 & 9.6 \\
Total & 52 & 8.6 & 0.9 & 0.1 & 6.5 & 10.2 \\
\hline
\end{tabular}

Table A4: ANOVA and Post-hoc LSD results of loss on ignition

\begin{tabular}{cccc}
\hline & Tree & & \\
Variable & Density & Test & Sig. \\
\hline LOI & $0-100$ & ANOVA/LSD & $<0.01$ \\
& $400-0$ & ANOVA/LSD & $<0.01$ \\
& $400-100$ & ANOVA/LSD & 0.21 \\
\hline
\end{tabular}

This article is protected by copyright. All rights reserved. 
Table 1: Mean infiltration capacities for depth and area

\begin{tabular}{lrrrr}
\hline Treatment & \multicolumn{2}{c}{$\begin{array}{c}\text { Std. } \\
{[\mathrm{mm} / \mathrm{h}]}\end{array}$} & $\begin{array}{r}\text { Deviation } \\
{\left[\mathrm{m}^{3} / \mathrm{h} / \mathrm{ha}\right]}\end{array}$ & $\begin{array}{c}\text { Std. } \\
\text { Deviation }\end{array}$ \\
\hline Pasture (0) & 37.7 & 24.4 & 376.6 & 244.4 \\
Silvo (100) & 34.6 & 42.5 & 345.3 & 425.4 \\
Clumped (400) & 209 & 103.7 & N/A & N/A \\
Clumped & & & & \\
Aggragated & N/A & N/A & 532.3 & 146.9 \\
\hline
\end{tabular}

Table 2: Comparison of statistical means tests

\begin{tabular}{cccc}
\hline Variable & Tree & Test & Sig. \\
\hline Soil Porosity & Pasture-Even & ANOVA/LSD & $<0.01$ \\
& Clump-Pasture & ANOVA/LSD & $<0.01$ \\
& Clump-Even & ANOVA/LSD & $<0.01$ \\
\hline Vol. Water & Pasture-Even & ANOVA/LSD & 0.19 \\
& Clump-Pasture & ANOVA/LSD & $<0.01$ \\
& Clump-Even & ANOVA/LSD & $<0.01$ \\
\hline \multirow{2}{*}{ Vol. Air } & Pasture-Even & ANNOVA/LSD & 0.53 \\
& Clump-Pasture & ANNOVA/LSD & $<0.01$ \\
& Clump-Even & ANNOVA/LSD & $<0.01$ \\
\hline
\end{tabular}

This article is protected by copyright. All rights reserved. 


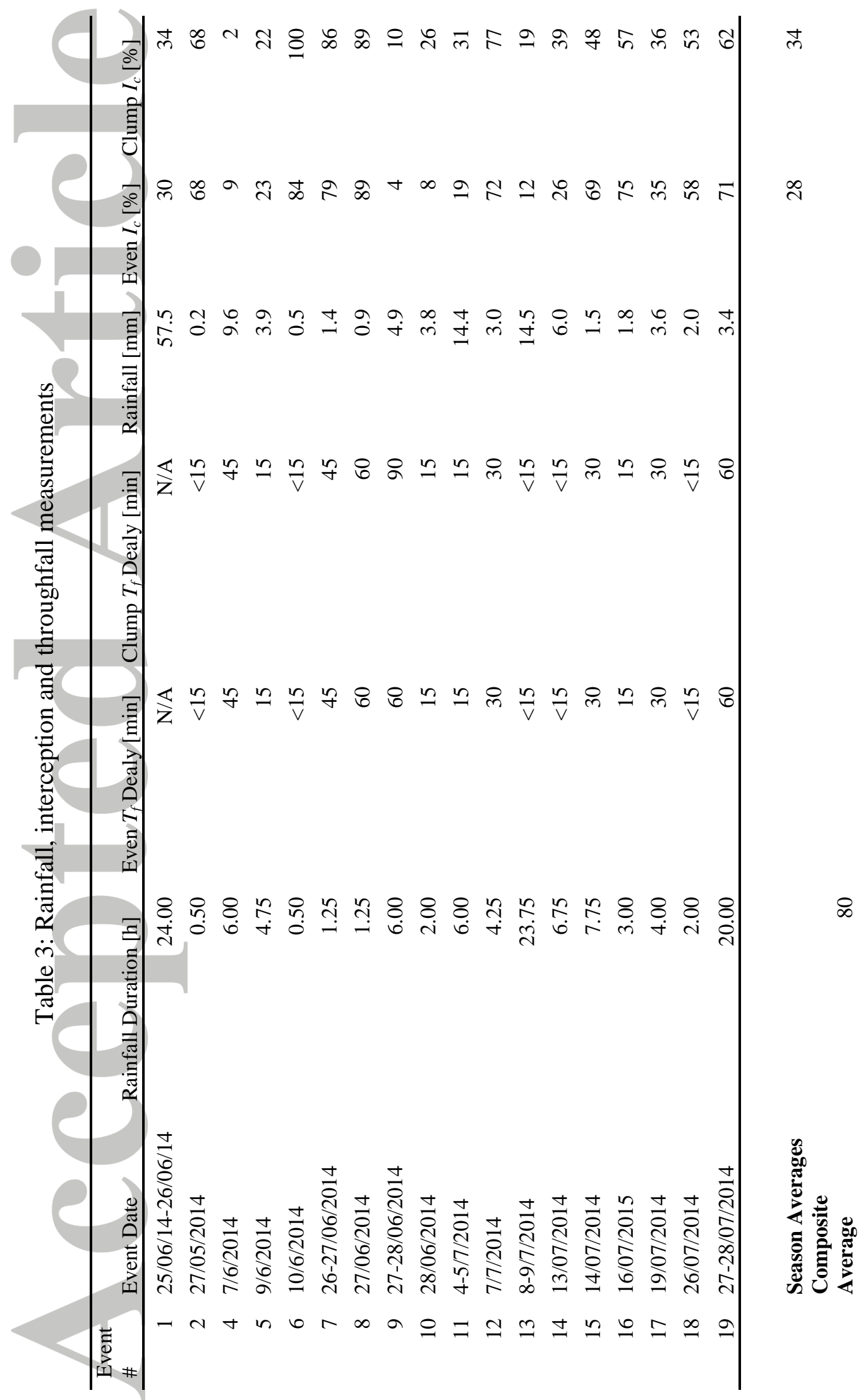

This article is protected by copyright. All rights reserved. 


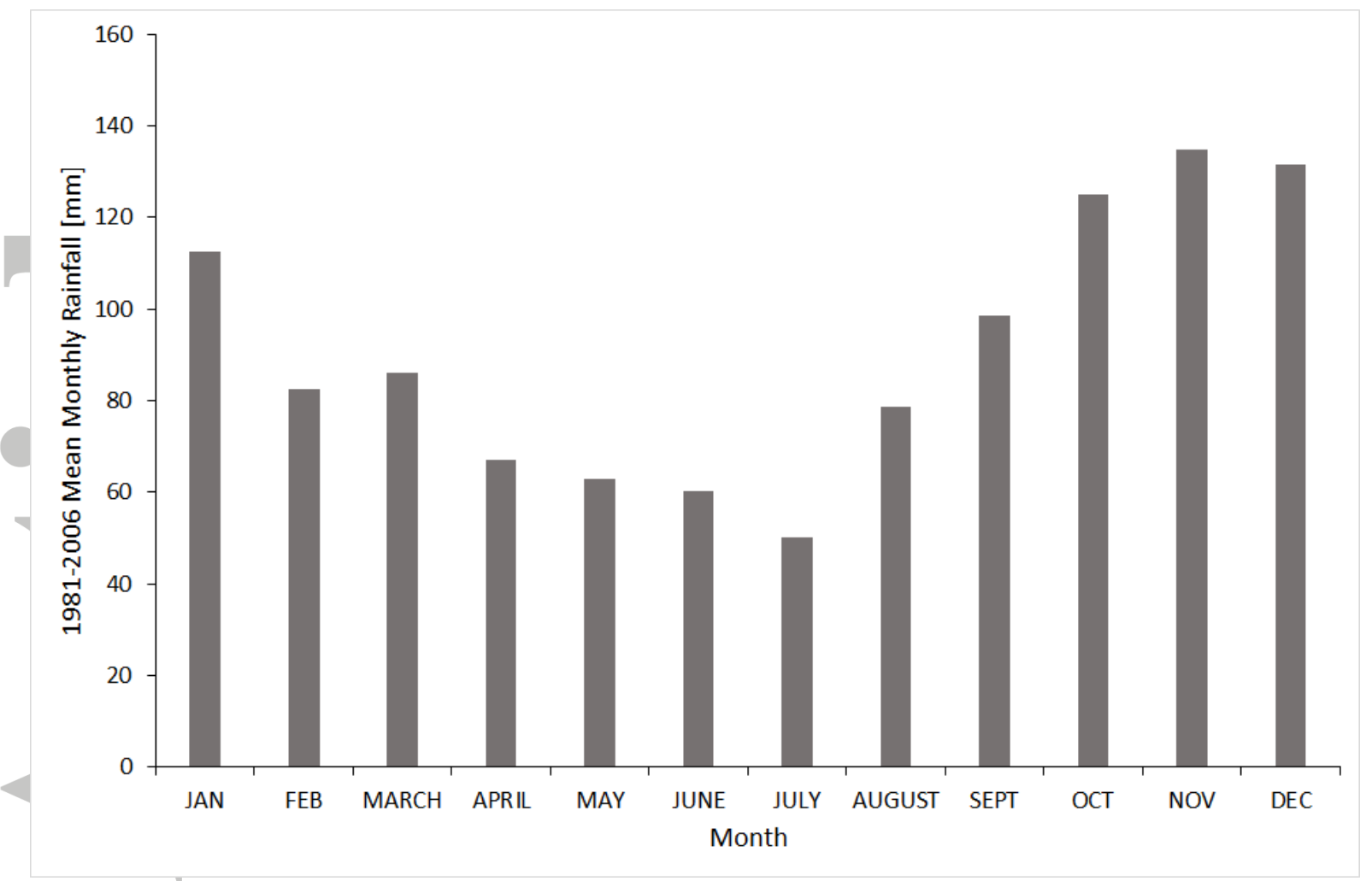

Figure 1: Mean monthly rainfall of the Henfaes Research Station 1981-2006.

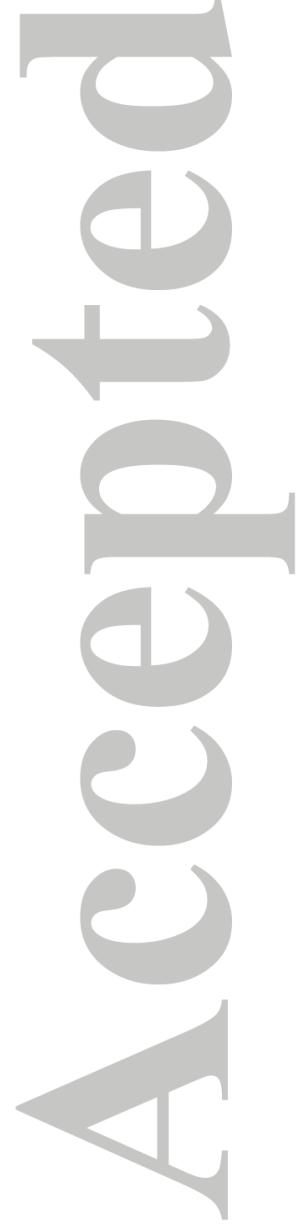

This article is protected by copyright. All rights reserved. 


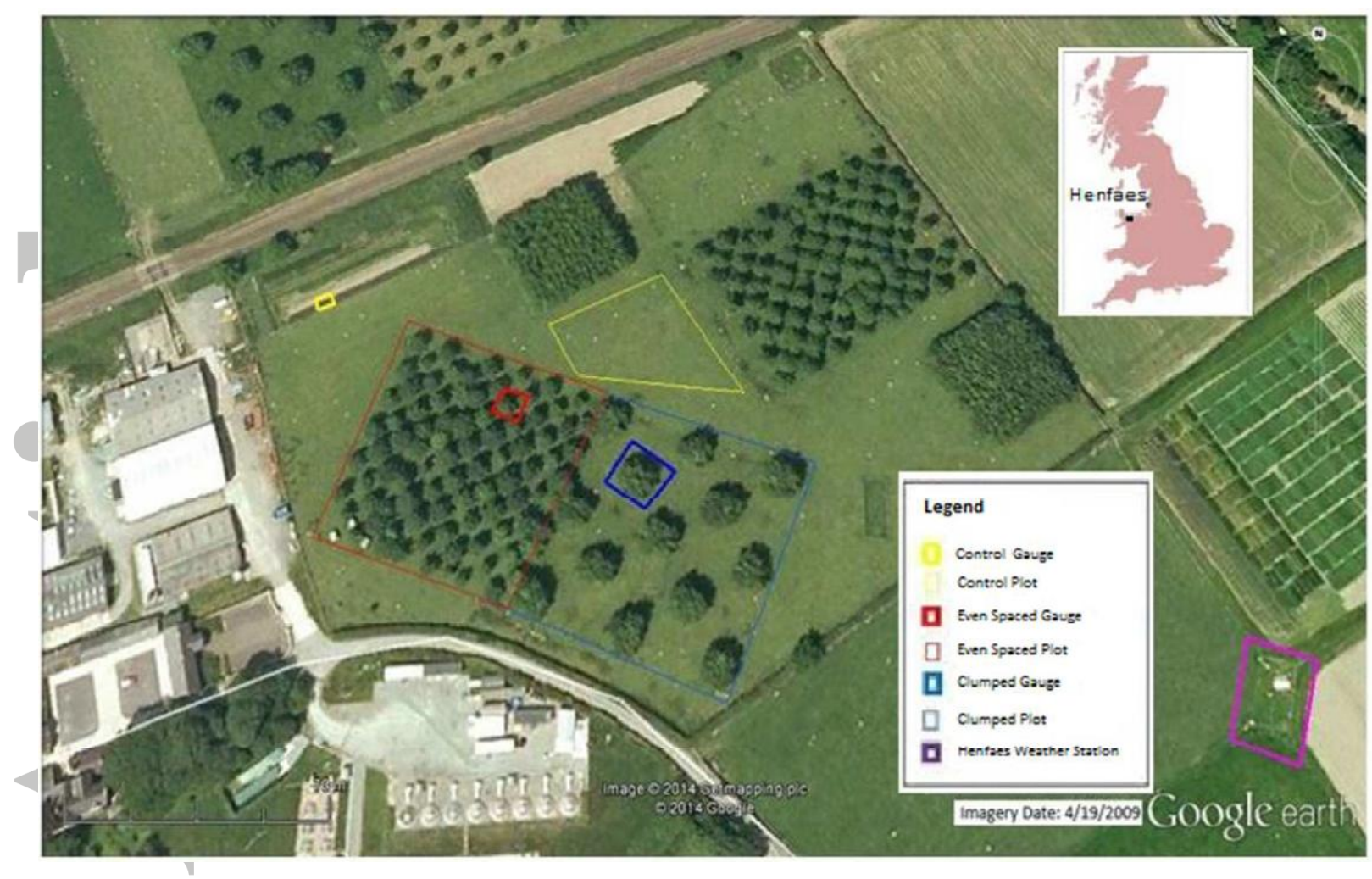

Figure 2: Site layout of Block III at Henfaes farm, North Wales, UK. Please note that this satellite image shows even spaced treatment plot prior to its 2013 thinning.

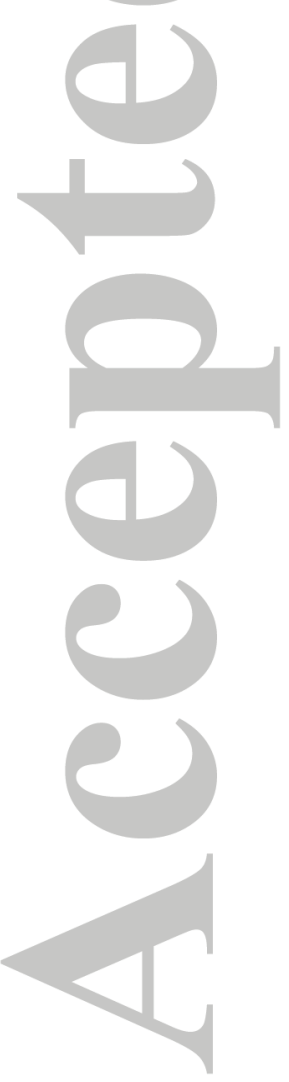

This article is protected by copyright. All rights reserved. 

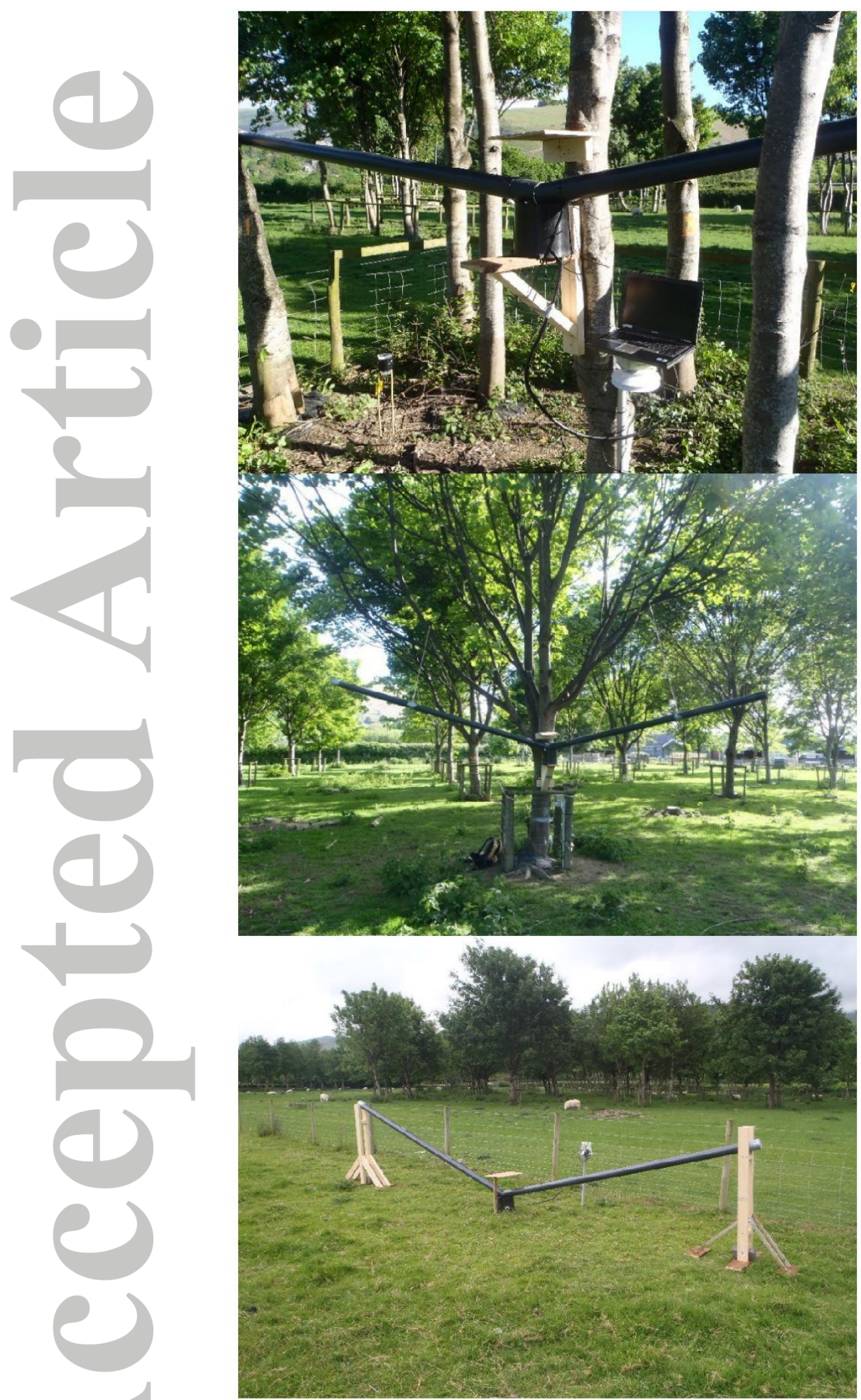

Figure 3: Throughfall and control gauges: clumped treatment (top) even spaced treatment (middle) and control gauge. 

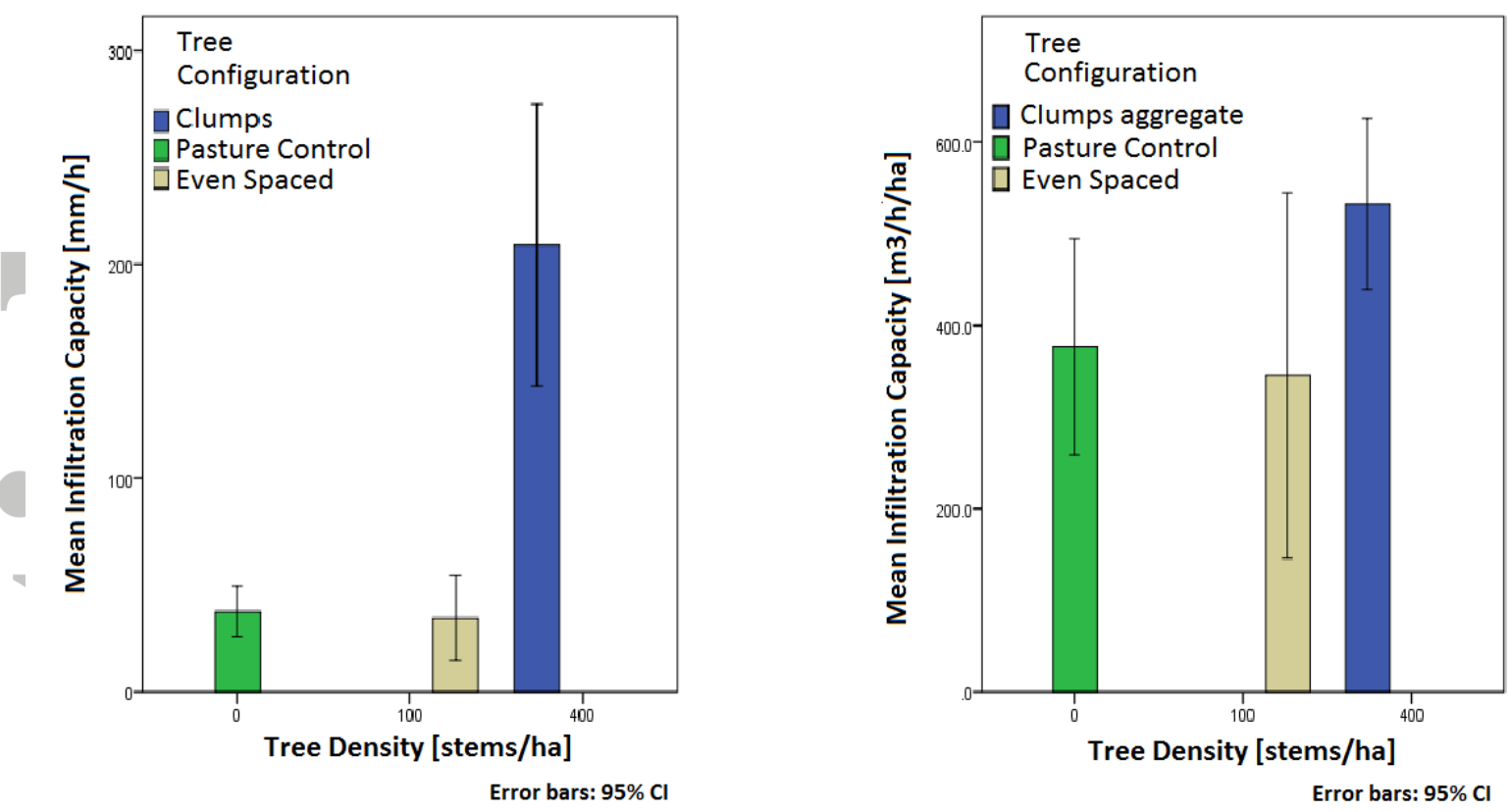

Figure 4: Mean soil water infiltration capacity (left) and aggregated infiltration capacity (right) for the control pasture, even spaced treatment, and clumped treatment.

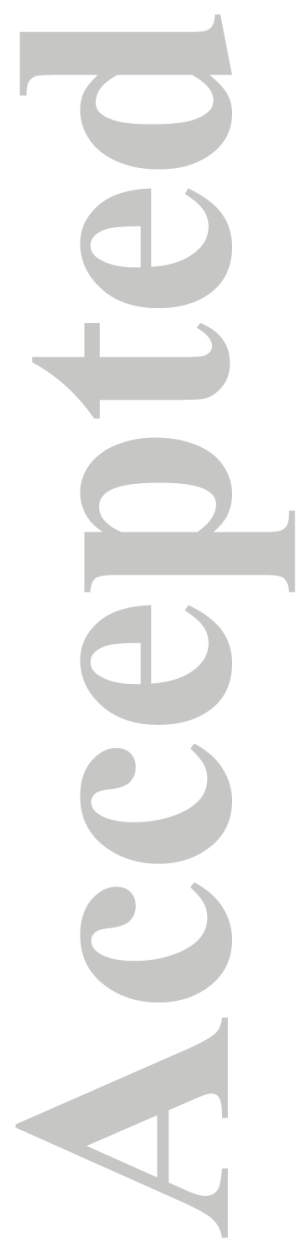

This article is protected by copyright. All rights reserved. 


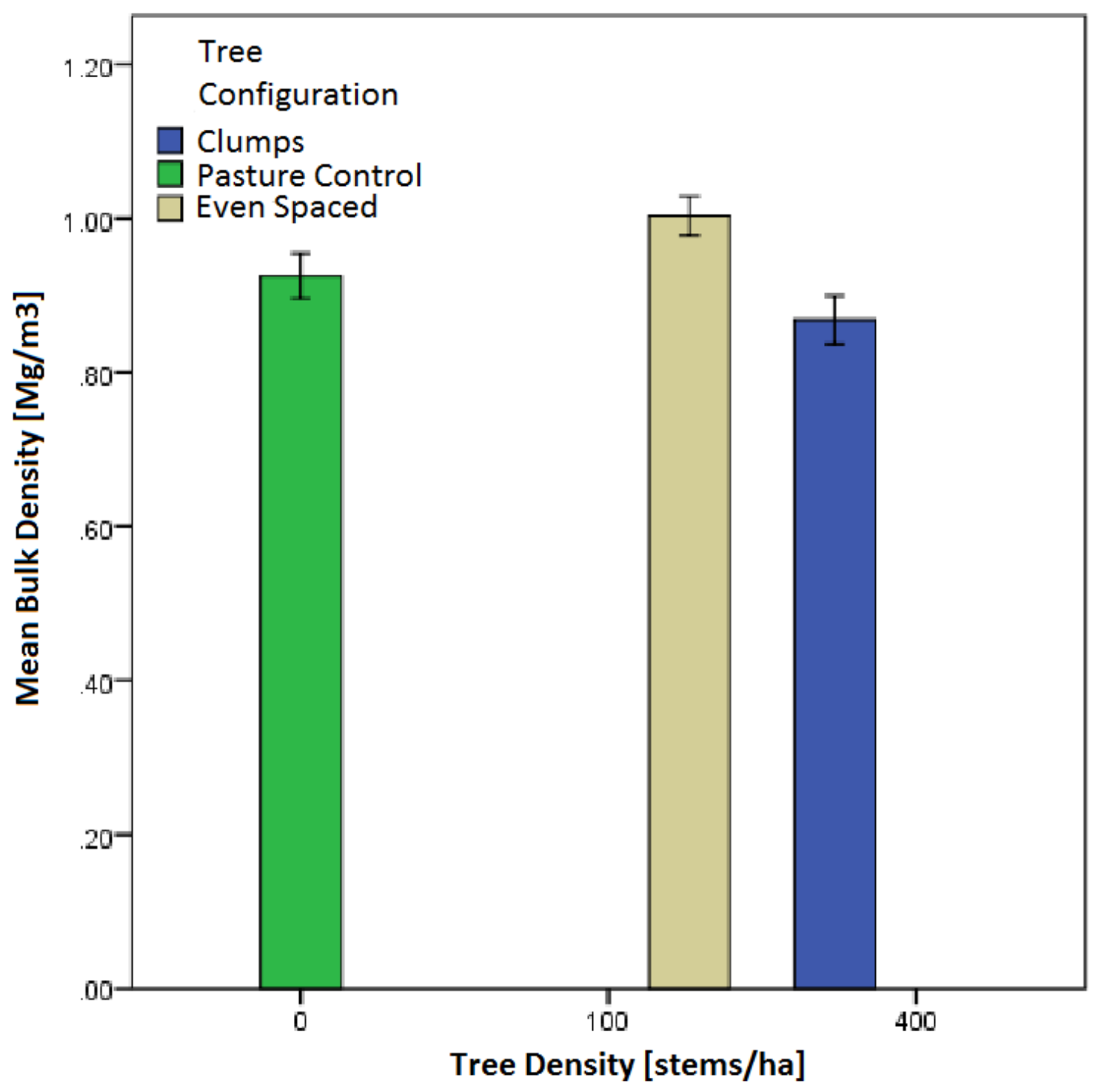

Error bars: $95 \% \mathrm{Cl}$

Figure 5: Mean soil bulk density of the control pasture, even spaced treatment, and clumped treatment. 


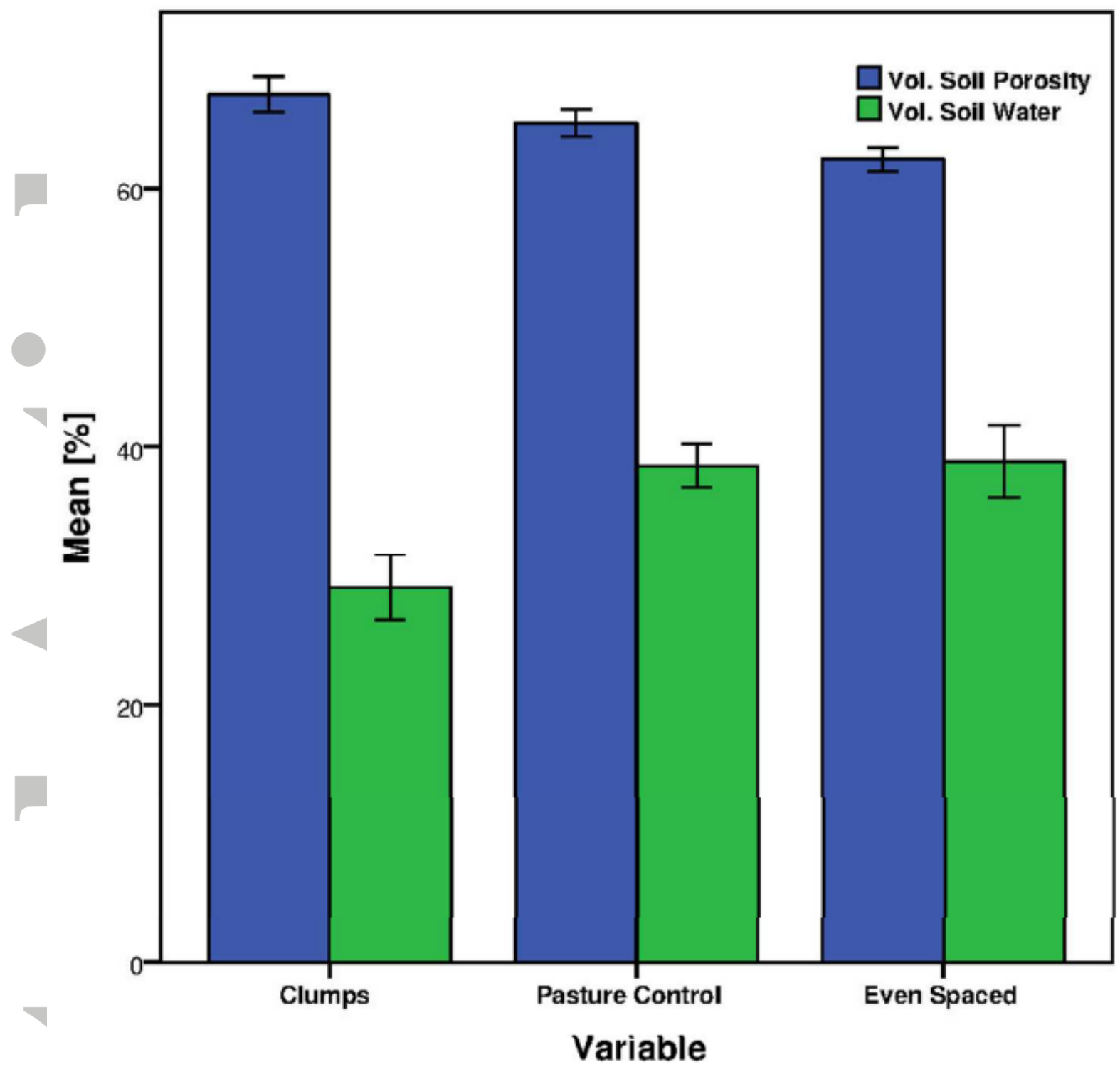

Error bars: $95 \% \mathrm{Cl}$

Figure 6: Mean soil porosity and portion of soil porosity as volumetric soil water content for the control pasture, even spaced treatment and clumped treatment. 


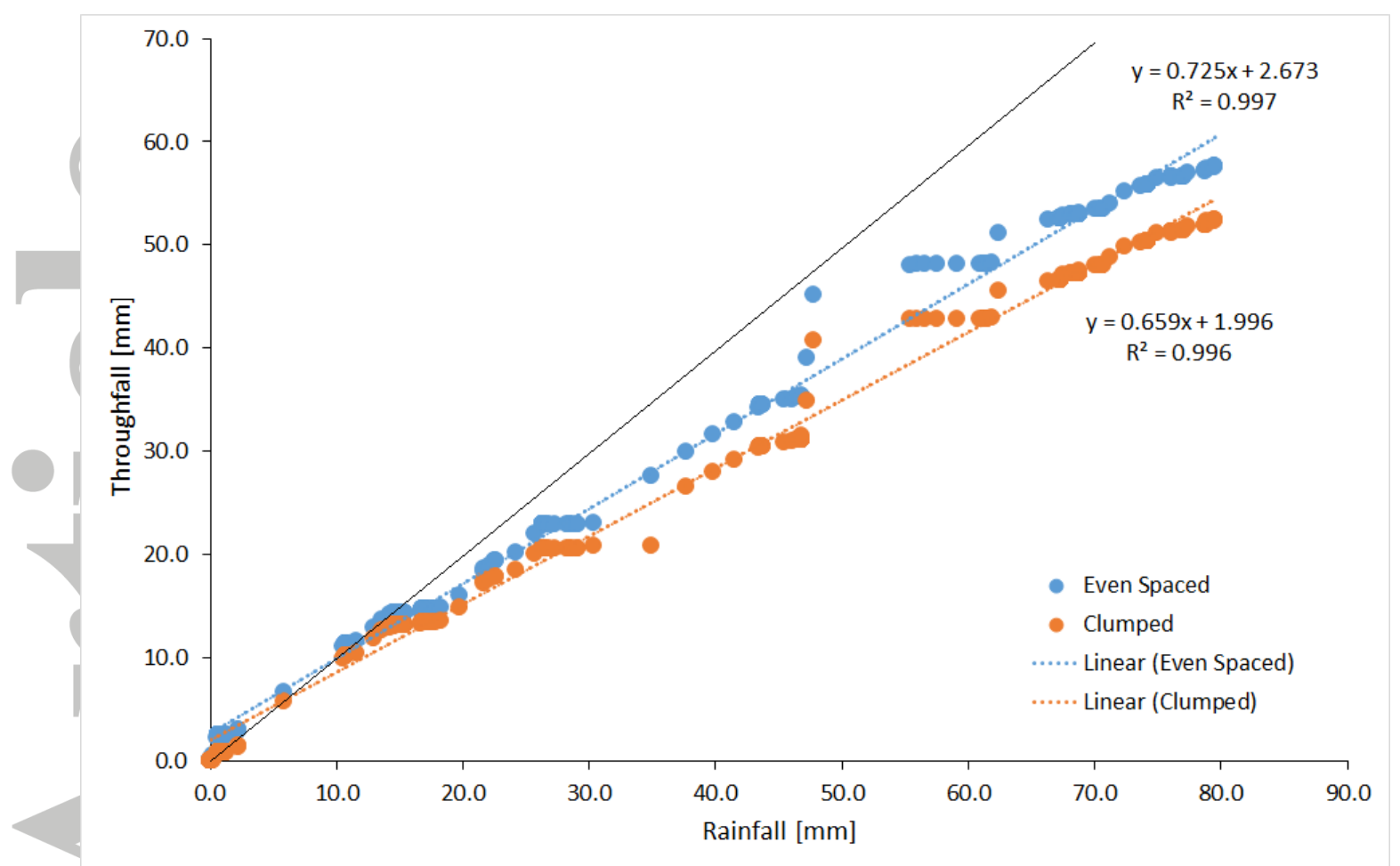

Figure 7: Relationship between cumulative rainfall and canopy throughfall for the even spaced and clumped treatments.

This article is protected by copyright. All rights reserved. 